San Jose State University

SJSU ScholarWorks

Master's Theses

Master's Theses and Graduate Research

Summer 2011

\title{
Analysis of Three Types of Sources to Determine the Existence of Native Bees in Historical San Francisco, East Bay Area
}

Sharon Lee Ordeman

San Jose State University

Follow this and additional works at: https://scholarworks.sjsu.edu/etd_theses

\section{Recommended Citation}

Ordeman, Sharon Lee, "Analysis of Three Types of Sources to Determine the Existence of Native Bees in Historical San Francisco, East Bay Area" (2011). Master's Theses. 4067.

DOI: https://doi.org/10.31979/etd.nt5t-unkg

https://scholarworks.sjsu.edu/etd_theses/4067

This Thesis is brought to you for free and open access by the Master's Theses and Graduate Research at SJSU ScholarWorks. It has been accepted for inclusion in Master's Theses by an authorized administrator of SJSU ScholarWorks. For more information, please contact scholarworks@sjsu.edu. 


\title{
ANALYSIS OF THREE TYPES OF SOURCES TO DETERMINE THE EXISTENCE OF NATIVE BEES IN HISTORICAL SAN FRANCISCO, EAST BAY AREA
}

\author{
A Thesis \\ Presented to \\ The Faculty of the Department of Geography \\ San José State University \\ In Partial Fulfillment \\ of the Requirements for the Degree \\ Master of Arts
}

by

Sharon L. Ordeman

August 2011 
(C) 2011

Sharon L. Ordeman

ALL RIGHTS RESERVED 
The Designated Thesis Committee Approves the Thesis Titled

\section{ANALYSIS OF THREE TYPES OF SOURCES TO DETERMINE THE EXISTENCE OF NATIVE BEES \\ IN HISTORICAL SAN FRANCISCO, EAST BAY AREA}

by

Sharon L. Ordeman

APPROVED FOR THE DEPARTMENT OF GEOGRAPHY

SAN JOSÉ STATE UNIVERSITY

August 2011
Dr. M. Kathryn Davis
Department of Geography
Dr. Richard Taketa
Department of Geography
Dr. Kathrine Richardson
Department of Geography 


\title{
ABSTRACT \\ ANALYSIS OF THREE TYPES OF SOURCES TO DETERMINE THE EXISTENCE OF NATIVE BEES IN HISTORICAL SAN FRANCISCO, EAST BAY AREA
}

\author{
by Sharon L. Ordeman
}

The arrival of the missionaries in the late eighteenth century began the transformation of the San Francisco East Bay area from wetlands to orchards, grain fields, and grazing lands. This research considers the possibility that European and American newcomers enlarged native bee ranges in the East Bay cities of San Leandro, San Lorenzo, and Hayward when imported pollen and nectar-producing flora were planted. Three types of sources are analyzed: journals and diaries of explorers, missionaries, and botanists; native bee and plant specimens collected before the Gold Rush in 1848; and ethnographies of Ohlone Native Americans. Conclusive evidence for the presence of bees in the research area prior to the arrival of the missionaries is lacking, whereas late twentieth-century studies suggest the likelihood that native bees existed before European settlements. 


\section{DEDICATION/ACKNOWLEDGMENT}

Dedicated to my most supportive fan-my husband, Erik.

I am grateful to the following people who asked the right questions at the right time, prodded me towards the finish line, and kept me motivated. Jamie, Tamiko, and Dave asked pointed questions which helped me focus on only the necessary and not the fluff. Dr. Kathryn Davis, my thesis advisor, encouraged me during those low points in the process to continue. Norm Penny, at the California Academy of Sciences, suggested invaluable research resources and the staff at the Hayward Area Historical Society diligently searched for relevant documents. Drs. Richardson and Taketa of the Geography Department provided their moral support and constructive feedback. My friends and neighbors continually encouraged me and brought me much-needed tea. 


\section{TABLE OF CONTENTS}

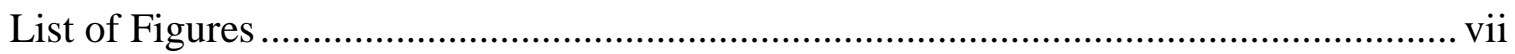

List of Tables …............................................................................................... viii

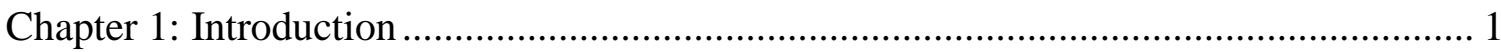

Chapter 2: Four Hundred Years of Environmental Change............................................ 3

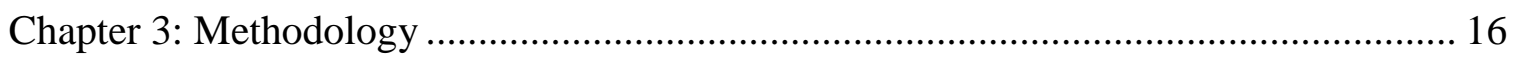

Chapter 4: Background on Bees and San Francisco Bay Estuary ................................. 22

Chapter 5: Written and Visual Clues in Journals and Diaries ..................................... 28

Chapter 6: Historical Native Bee and Plant Specimens ............................................. 41

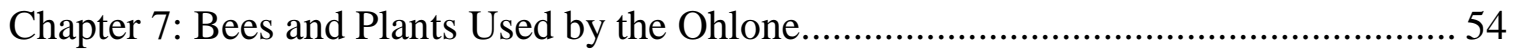

Chapter 8: Native Bees in Historical East Bay .................................................... 58

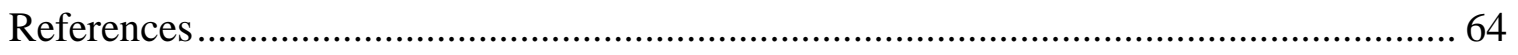

Appendix: Presence of Vegetation in pre-Gold Rush East Bay ................................... 71 


\section{LIST OF FIGURES}

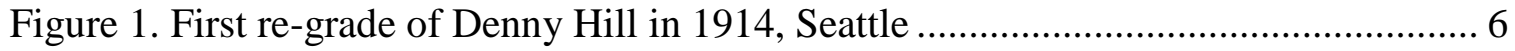

Figure 2. Map of Bay Area with research area outlined ........................................ 13

Figure 3. Past and present wetlands along the East Bay.......................................... 18

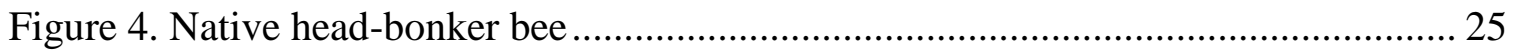

Figure 5. Looking across estuary in Coyote Hills Regional Park .................................. 27

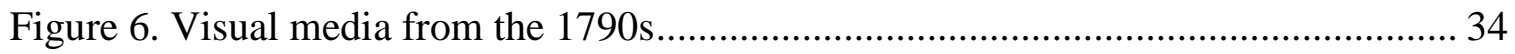

Figure 7. Engraving of Perdrix, male et female, de la California ................................. 35

Figure 8. Engraving of A Remarkable Mountain near the River of Monterrey, 1790s .... 36

Figure 9. View of 1840s San Francisco looking eastward.......................................... 37

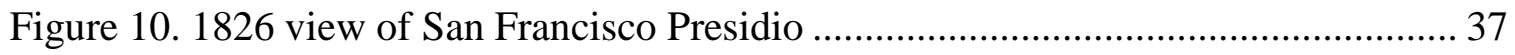

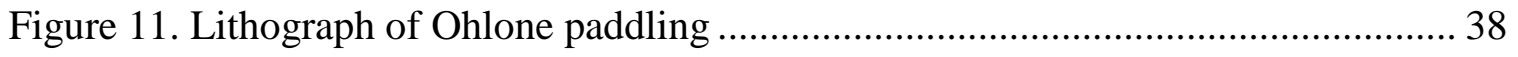

Figure 12. Drawing of and by 1800s naturalists, present-day photograph of a poppy ..... 39

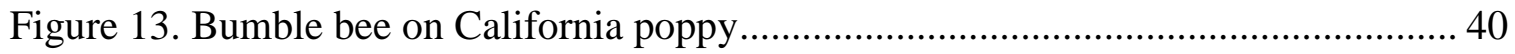

Figure 14. Hills in Garin/Dry Creek Regional Park, Hayward..................................... 56

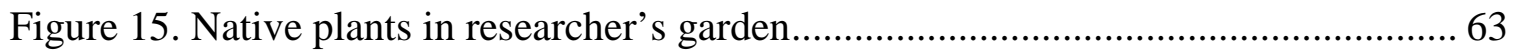




\section{LIST OF TABLES}

Table 1. On-site tally of bumble bee specimens ....................................................... 43 


\section{Chapter 1: Introduction}

The arrival of European and American settlers permanently changed California's wildlife environment by introducing non-native flora and fauna and eliminating much of the native habitats before the endemic wildlife was taxonomically identified. San Francisco Bay's extensive wetlands, over time, were converted to orchard, crop, and grazing lands when missionaries, rancheros, and pre-Gold Rush Europeans and Americans settlers arrived in the area. Agricultural and horticultural plants were introduced, many of which required pollination by insects, specifically bees, for successful production. However, honey bees were not imported until the 1850s (Office of Historic Preservation, 2011; Horn, 2005), so pollination must have been provided by native bees.

Historical data on California's flora and fauna is sparse because California was unfamiliar to people before gold was discovered in 1848. This research analyzed three types of sources-journals and diaries of explorers, missionaries, and botanists; native bee and floral specimens collected before the Gold Rush; and ethnographies of Ohlone Native Americans_-for verification that native bee species existed 250 years ago along the estuarial eastern shoreline of the San Francisco Bay (known as the East Bay).

The colony collapse disorder of honey bees has focused attention on the value of native bees for agricultural pollination services, and present-day studies (discussed in Chapter 4) have shown that native bees search (forage) for pollen and nectar from native, non-native, and introduced (exotic) flora. The primary working assumption for this research is that native bee food and habitat requirements have not changed since the mid- 
eighteenth century. Introduced pollen and nectar-producing plants by eighteenth-century Europeans could have expanded native bee foraging and habitat environments as the wetlands were converted to a drier environment, unless historical sources provide evidence that native bees existed in the East Bay before the arrival of Europeans. 


\section{Chapter 2: Four Hundred Years of Environmental Change}

Land cover along the eastern coastline of San Francisco Bay became increasingly more exotic (plants whose origins are from outside of the United States) by the midnineteenth century after the arrival of permanent settlements by Spanish missionaries, rancheros/Californios, and pre-Gold Rush European and American settlers. The influx of exotic vegetation and domesticated animals had a dramatic impact on California's native flora and fauna, similar to the environmental impacts that occurred in seventeenth and eighteenth-century New England, nineteenth-century Midwest Plains, and early twentieth-century Seattle. "So with dredge and dyke, tile and torch, we sucked the cornbelt dry, and now the wheatbelt. Blue Lake becomes green bog, green bog becomes caked mud, caked mud becomes a wheatfield" (Leopold, 1966, p. 172). Leopold succinctly described the changes that Euro-American settlers incurred when the environment was forcibly altered to suit economic needs.

New England was inhabited for centuries by Native Americans who hunted, gathered, and cultivated the land. The first European settlers viewed not a pristine wilderness untouched by humans, but an environment that was cleared by hand or intentionally burned (these practices were more common in southern New England where climate and topography allowed for a more settled lifestyle). The constant clearing activities allowed chestnut, oak, and other re-sprouting trees to thrive while beech, junipers, and white pines were suppressed (Cronon, 2003; Hall, Motzkin, Foster, Syfert, \& Burk, 2002), and the burning improved soil nutrients and friability, decreased the number of plant diseases and 
fleas, and allowed the soil to stay drier permitting growth of preferred vegetation (Cronon, 2003).

The New England ecosystems changed slowly on a regional scale but rapidly on a local scale when Europeans settled in the early seventeenth century. Burning was discouraged, cattle grazed freely, exotic crops (weeds) were sowed, and land was enclosed in miles of fencing. Timber shortages were experienced in Boston by 1638 . The flora and fauna that William Wood described in 1633 had disappeared by the midnineteenth century according to Henry David Thoreau. Nineteenth-century naturalists wrote that the deforestation of New England was responsible for warmer and drier soil, increased seasonal temperature variations (hotter summers and colder winters), increased flooding, larger mosquito populations, and poorer drainage. Present-day New England forests are second and third-growth forests that support different ecological communities from the original forests of four hundred years ago (Cronon, 2003). Within two hundred years of the first permanent settlement, much of New England changed from a forested and subtly modified natural environment to a thickly settled and highly altered environment.

The European culture of permanency and trade impacted the indigenous (found only in a localized area) flora and fauna. Cattle grazing decimated indigenous vegetation, newly built roads changed flora and fauna habitats, plowing eradicated native ecosystems and promoted European plant species that thrived in disturbed soil, and farming practices caused sediment changes, soil exhaustion, and weed and pest infiltrations. New England 
ecological communities became an economical environment as European settlers treated their natural surroundings as commodities, influenced by market demand (Cronon, 2003).

Similar environmental changes occurred on the vast plains of the Midwest as EuroAmerican settlers pushed westward during the nineteenth century. Native Americans incurred subtle changes to the Midwest's ecosystems over the centuries with prescribed fires and simple irrigation systems. However, alterations made by Euro-American settlers were noticeable within a few decades as the flora and fauna became more exotic and less indigenous, and as hunting and trapping decimated bison, wolves, prairie dogs, and grizzly bears (Flores, 2001). Cattle were introduced, although Flores (2001) contended they were not as detrimental as in New England because they replaced another herbivore - the bison. He believed irreparable changes occurred from the importation of exotic European plants such as tumbleweeds and grasses, the loss of riparian ecosystems, and the spread of shrubbery due to the lack of intentional burning. Trees were felled for fuel, fences, and structures, streams and rivers were channeled for irrigation, thousands of sheep and cattle overgrazed the grasslands, and thousands of acres of crops were planted—all of which impacted the native ecosystems (Flores, 2001).

The twenty-first century Midwest has pockets of densely populated cities with thousands of acres of plains surrounding them, whereas New England is a heavily populated region. Both regions have experienced the visible and irreversible habitat changes of their native flora and fauna. But the Midwest has an additional critical issue of water. Its primary underground source of water, the Ogallala Aquifer, is shrinking due to increased population and agriculture needs. The ecology of the Midwest has 
experienced major changes within the past two centuries, above and now below the surface.

Seattle, Washington, occupies a much smaller area than the regions of New England and the Midwest Plains and is renowned for its lush natural environment and its environmental thoughtfulness. However, Seattle was a " "perennial gale of creative construction"' (Klingle, 2007, p. 181) during the first half of the twentieth century as its hills were re-graded or entirely removed (see Figure 1), marshlands were resolutely filled in, hillsides deforested, and rivers and streams were re-engineered in such a way that today's drainage basin is entirely different from two hundred years ago. The attitude during this period of time was "nature altered was nature perfected and society harmonized" (Klingle, 2007, p. 5).

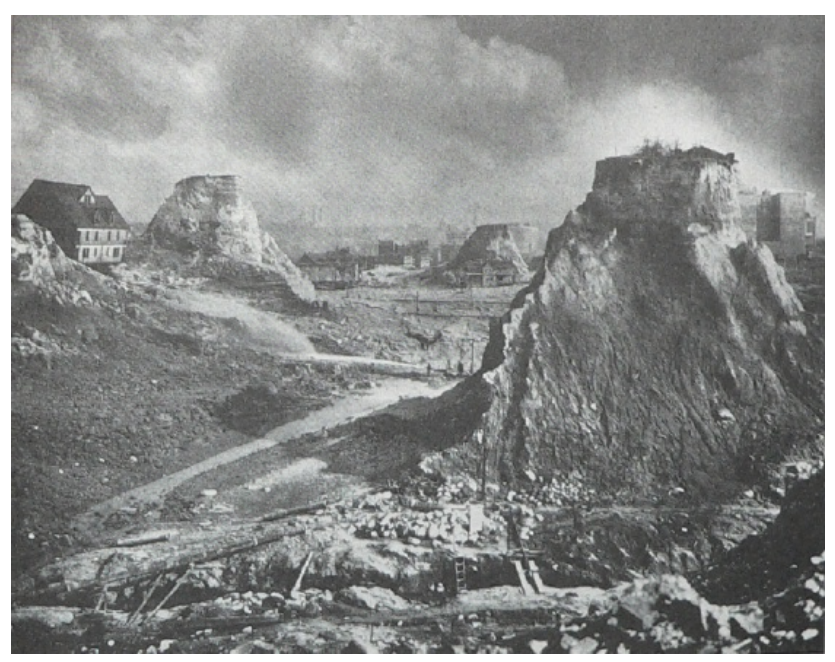

Figure 1. First re-grade of Denny Hill in 1914, Seattle (Klingle, 2007, between pp. 7677). Photograph by Asahel Curtis. Courtesy Special Collections, University of Washington Libraries, UW 4812. 
Puget Sound was discovered by Captain George Vancouver in 1792, and by the early 1850s, European and American homesteaders and industrialists claimed the land from the Native Americans, determined to create a world-class shipping port and to develop lucrative real estate sites. Many decades of environmental changes were publically supported and financed with engineers, landscapers, real estate agents, and railroad magnates advocating changes to support their own political and economic agendas. Environmental alterations in Seattle and its environs were calculated activities and each decade of change compounded the original alterations (Klingle, 2007).

The natural environment in and surrounding Seattle cannot be restored to a specific point in time just as New England and the Midwest can never revert back to their preEuropean environments. Cronon (2003), Flores (2001), and Klingle (2007) acknowledged that the natural environments were never pristine wildernesses because Native Americans conscientiously maintained them. Euro-American settlers radically changed these native environments because the natural resources were treated as unlimited commodities and their arrival to California incurred equally devastating results.

Discovery of gold in California in 1848 brought an influx of people to San Francisco and Sacramento within months of the announcement. However, changes to California's ecosystems began long before 1848. The earliest European explorers left behind weed seeds. Missionaries established fledgling agriculture and livestock industries that the rancheros/Californios expanded upon. The pre-Gold Rush European and American settlers began trade industries based on natural resources. The arrival of these various groups, while small in numbers compared to the number of gold seekers, incurred large 
environmental transformations to portions of California between 1767 and 1848. The following pages high-light the major changes that occurred during this timeframe.

The majority of California's Native Americans were seasonally semi-nomadic to take advantage of available flora, fauna, water, and shelter. They were hunters, gatherers, and fishermen who enhanced their surroundings by burning, hand clearing, tilling, irrigating, and pruning. To the European newcomers, the wilderness had the appearance of a landscaped scene (Anderson, 2005; Preston, 1998). The population of California's indigenous people was approximately 300,000 by the mid-eighteenth century (Beebe and Senkewicz, 2001, p. 479; Anderson, 2005, p. 34), but their cultures varied geographically as the seasonality and location of the indigenous flora and fauna determined when and where they hunted, fished, gathered seeds, and sowed plants for food, medicine, shelter, clothing, and basketry. Tribelets (smaller groups within a tribe) alternated between villages based on the plenteousness of the flora and fauna, thus long distance travelling was not necessary although trade between tribes was a very common practice (Anderson, 2005; Margolin, 1978). Native Americans adapted to and thrived within their natural environment centuries before the first Europeans set foot on California land.

The topography of California slowed the progress of exploration and the arrival of permanent settlements as the mountains, large arid valleys, and rocky and foggy coastlines presented physical barriers. The land in California was not under the firm control of any one nation by the eighteenth century, so the Spanish Crown, using Mexico as its base, instructed its explorers to search for wealth, a short-cut to the Philippines, and viable harbors and lands that could support thriving towns and farms. The explorers 
embarked from Mexico into Baja California, then traveled northward leaving behind seeds of exotic flora that survived in the disturbed soil and manure (Preston, 1998; Rawls and Bean, 1998; Minnich, 2008). By the late eighteenth century, Spain had established the mission system throughout California to solidify its claim to the land.

Twenty-one missions, three presidios (military outposts), and two pueblos (towns independent of the missions) were established in California between 1769 and 1823. An individual mission typically encompassed thousands of acres of land, was managed by a few non-indigenous workers and religious staff, and labored by the Native Americans with the expectation that they would convert to Catholicism and Spanish culture, thus ensuring Spanish ownership of the lands (Hornbeck, 1983; Rawls and Bean, 1998; Beebe and Senkewicz, 2001). Each self-sustaining mission raised cows, sheep, horses, grapevines, corn, wheat, oats, various vegetables, and fruit trees (brought from Spain via Mexico), and manufactured its own goods such as candles, soap, pottery, and leather goods (Soulé, Gihon, \& Nisbet, 1855; Preston, 1998; Rawls and Bean, 1998). Successful missions owned thousands of domesticated animals that grazed freely, and grew thousands of bushels of crops such as corn, wheat, and barley (Soulé et al., 1855; Hornbeck, 1983).

A very small number of non-indigenous people wrought substantial changes to California's natural environment. Only 150 non-indigenous people lived in California in 1770 and approximately 3,400 non-indigenous people lived in missions, presidios, and pueblos by 1820 (Hackel, 1998, p. 122). European weeds had already naturalized by 1769 as evidenced by weed seeds found in adobe bricks of southern California missions, 
possibly left by Cabrillo in 1542 or 1543 or by Vizcaíno in 1602 or 1603 (Preston, 1998; Minnich, 2008). Large numbers of livestock and acreage under tillage eradicated sensitive native flora. The decimation of Native Americans also played a major role with environmental degradation because the lack of land management allowed introduced plants to out-compete the native flora (Preston, 1998). The missionaries had established permanent settlements and the foundation of farming and grazing that continued when Mexico took control of the land.

In 1821, Mexico won independence from Spain and now governed Baja California and Alta (present-day) California. The missions were secularized over the next ten years; their lands were divided into very large ranchos and granted to ex-military and government servants as rewards for their services. According to Rawls and Bean (1998) each rancho was to be no larger than 50,000 acres or 76 square miles (p. 61) and was to contain woodlands for buildings, fuel and food, grazing lands for domesticated animals, rivers/streams for irrigation, and fertile soil for crops.

The number of ranchos increased over the next twenty years (Hornbeck, 1983), and by 1840 the total population of the rancheros and Californios (born in California during Mexican rule) rose to approximately 7,000 (Beebe and Senkewicz, 2001, p. 482). Even though the rancheros and Californios did not view their surroundings as economic commodities, the increase in individual ranchos meant more areas of indigenous flora and fauna were overrun with domesticated animals and exotic vegetation (Rawls and Bean, 1998). The major trade was cattle hides and tallow; crops were raised only for the needs 
of the rancho. Few non-Mexicans settled in Alta California during the 1820s; most were traders and farmers who assimilated into the Californios' culture.

A cultural shift regarding natural resources occurred by the 1840s as more nonMexican than Mexican immigrants had entered California (Rawls and Bean, 1998; Beebe and Senkewicz, 2001). These settlers believed that California was a land of commodities and therefore wealth: forests for timber and animal pelts, rivers for fish, bays for shellfish, and land for crop growing and for sale. This new attitude towards California's flora and fauna transformed the state's ecological environments before early nineteenthcentury naturalists and botanists began cataloging. As early as 1841, Mariano Guadalupe Vallejo complained to his superiors that otter and beaver had been exterminated (Vallejo, 1841/2001). Forests began to disappear when early nineteenth-century Russian, American, and English settlers arrived, as timber was used extensively in their cultures. Land-use changes by Spanish explorers, missionaries, and rancheros/Californios became irreversible, but forests were spared because timber was not valued as much as adobe (Preston, 1998).

California became a territory of the United States in 1848 and, within months, gold was discovered. The impacts on the natural environment of the Gold Rush extended beyond the immediate destruction of streams and hills. The increased population needed food, particularly beef, so cattle prices soared from $\$ 5.00$ a head in 1846 to $\$ 500.00$ a head in 1849 (Rawls and Bean, 1998, p. 160). The demand induced ranchers from the Midwest and Southwest to drive herds of cattle overland, trampling indigenous flora en route. By 1860, approximately three million cattle (Rawls and Bean, 1998, p.160) were 
in California. Agriculture was not as lucrative as cattle; nevertheless, by 1855, the foundation of the fruit and vegetable industry was well established and, by 1860, wheat was California's most important crop. The timber industry boomed as it supplied wood for sluices, flumes, shelters, mining shafts, carriages, towns and fences; consequently, the remaining old-growth forests around the San Francisco Bay were decimated by 1870. The increase in sheep further reduced the floral diversity as the textile industry flourished (Rawls and Bean, 1998).

Within a decade of the Gold Rush, debris from the miners' hydraulic hoses caused problems in streams, rivers, the Delta region, and ultimately the San Francisco Bay as toxic minerals, rocks, dirt, and vegetation altered the water and riparian environments. Levees and large irrigation ditches in the Central Valley impacted flow rates and freshwater levels of the Sacramento and San Joaquin Rivers. Dredging became commonplace and riparian environments disappeared as settlers strove to change the current environment into money-making ventures. By the end of the 1860s, the Southern Pacific Railroad arrived in the San Francisco Bay Area allowing industry and agriculture to expand further (Mount, 1995).

The East Bay was not immune to the ecological changes caused by the aforementioned inhabitants as its missions, pueblos, and ranchos were well established before the Gold Rush. The original inhabitants were the Yrgin and Tuibun tribelets of the Ohlone tribe who hunted, fished, gathered various plants, and sowed seeds between the Bay and the Coast Range foothills and valleys (Margolin, 1978). Mission San José, the only mission on the eastern side of San Francisco Bay, was established in 1797 in 
present-day Fremont (see Figure 2). The lands of Mission San José, which were the lands of the Yrgin and Tuibun, stretched from the mission north to present-day Oakland, east to Mount Diablo, and west to the Bay. Grazing lands fluctuated seasonally and extended 40 miles northeastward to the Sacramento and San Joaquin Rivers. The missionary's work of converting the Native Americans to Catholicism extended 55-70 miles in all directions from the church's location (McCarthy, 1958). Wheat, Indian corn, barley, peas, beans, pears, apricots, apples, and grapevines grew quite successfully after a few years of tending (Soulé et al., 1855; Farnham, 1856). During the late 1820s, the mission was secularized, and its land was divided into several ranchos.

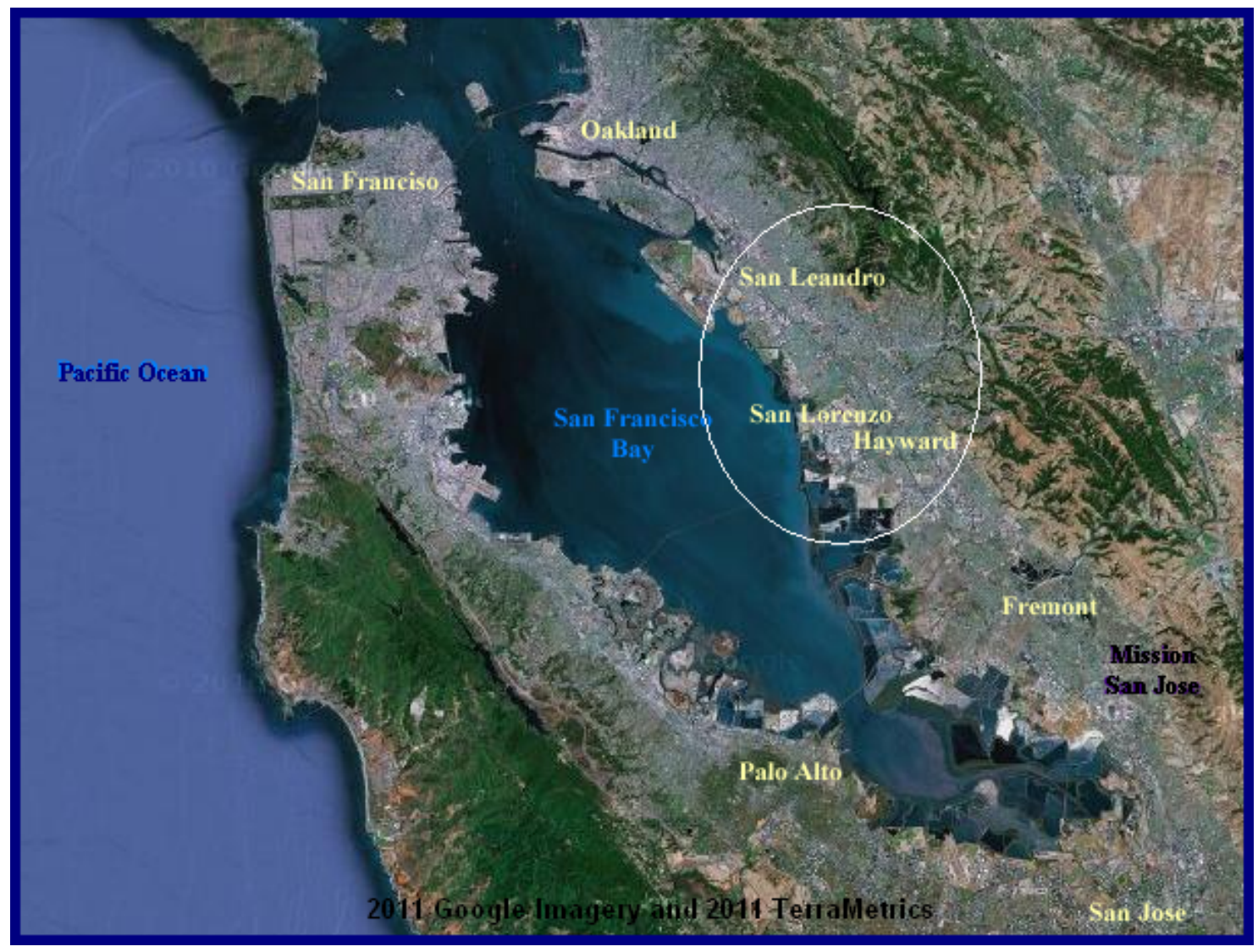

Figure 2. Map of Bay Area with research area outlined. Cities added by author; research area outlined in white. Data retrieved from Google Maps (2011). 
Farming was the primary industry in the East Bay before the Gold Rush. The area from San Pablo to San Jose was a continuous grain field according to Harlan (1888), and wild oats grew throughout the area (Minnich, 2008). Mustard (Brassica spp.), an exotic weed, was so high and so dense that horses had difficulty getting through and farmers constantly complained (Minnich, 2008). The bourgeoning Gold Rush population ensured the continued profitability of agriculture in the East Bay, but made the study of native ecosystems very difficult because of the incurred changes. By 1870, Alameda County (which also included lands eastward to present-day Livermore) produced over 850,000 bushels of wheat, 114,000 bushels of Irish potatoes, and 668,000 bushels of barley. Wool, wine, butter, and cheese were also produced (Thompson and West, 1878/1976). A farmer's success was portrayed in lithographs in Thompson and West's (1878/1976) New Historical Atlas of Alameda County: huge farm houses surrounded by manicured lawns and tidy rows of fruit trees. The park-like wilderness had become a highly cultivated environment.

The Ohlone, European explorers, missionaries, rancheros and Californios, early European and American settlers, and then gold seekers changed the natural environment with varying degrees of degradation to the native ecosystems. By the end of the nineteenth century, East Bay residents encountered severe soil and water pollution, deforestation, and undesirable weedy grasslands. Towns grew from a few inhabitants in the early nineteenth century to hundreds by the early twentieth century. Residents dried the interior and shoreline wetlands and converted them to salt ponds, businesses, and residential areas. Today, the East Bay is a thriving metropolitan area where a diversity of 
native bee species appears in urban flower and vegetable gardens. The question of how these present-day native bees came to be present is the basis of this research. 


\section{Chapter 3: Methodology}

The research for this project divided the inhabitants of pre-Gold Rush California into five major groups based on their impacts on California's natural environment: Native Americans, specifically the Ohlone tribe, Spanish explorers, missionaries, rancheros and Californios, and pre-Gold Rush European and American settlers. The Ohlone subtly tended to their surroundings to ensure the continuation of native flora and fauna and their oral observations, centered on the natural environment, were passed from one generation to the next. The Spanish explorers searched for wealth, a shorter passageway to Asia, and expansion of land holdings, so their written observations were biased towards the likelihood of successful settlements and discovery of gold and silver.

The missionaries' two goals were to convert the Native Americans to Catholicism and to establish self-sustaining settlements. The missions' self-sustainability depended on the productivity of the introduced exotic vegetation that required pollination by insects, best done by bees; their orchards and grain fields were well established within a decade of being sown. Missionaries often described the natural surroundings but their writings focused primarily on the indigenous population. The rancheros/Californios continued the missionaries' agriculture and cattle-grazing practices when they became owners of the secularized mission lands during the 1820s. The attitude of using natural resources for personal economic gain was not part of the culture although acres of crops, free roaming herds of cattle and enlarged irrigation systems impacted local environments. The preGold Rush European and American settlers assimilated into the Californio culture, but several developed a fledging trade industry based on resource consumption. 
The date of the Gold Rush—1848_-was used as the cutoff date for this project because 1) the number of pre-Gold Rush European and American settlers in the San Francisco Bay Area was extremely small compared to the large numbers that arrived to seek gold. The smaller number of inhabitants implied fewer number of changes to the environment; 2) changes to the native flora were slower and the impacts were less severe, even with the intentionally introduced exotic plants; and 3) changes to indigenous floral communities by pre-Gold Rush settlers would not have exterminated the native bees, even though the bees' habitat and foraging needs would have been impacted. The date of the first mission in San Francisco Bay Area-1776-was not chosen as the cutoff date because the number of written resources was much smaller and less likely available for public use.

The research area for this project was the combined areas of present-day cities of Hayward, San Leandro, and San Lorenzo, California—collectively known as the Hayward Area (see Figure 2). The historical wetlands in the Hayward Area had been altered by varying degrees by the presence and activities of the Ohlone, Spanish missionaries, and Mexican rancheros, but by the end of the nineteenth century, the natural wetlands began to disappear (see Figure 3) when they were altered to support non-native agriculture and landscapes thereby obliterating the endemic flora and fauna that had flourished. 
Historical Wetlands Circa 1800

Transparent Colors Overlaid on

Present-day San Leandro-Hayward-Newark

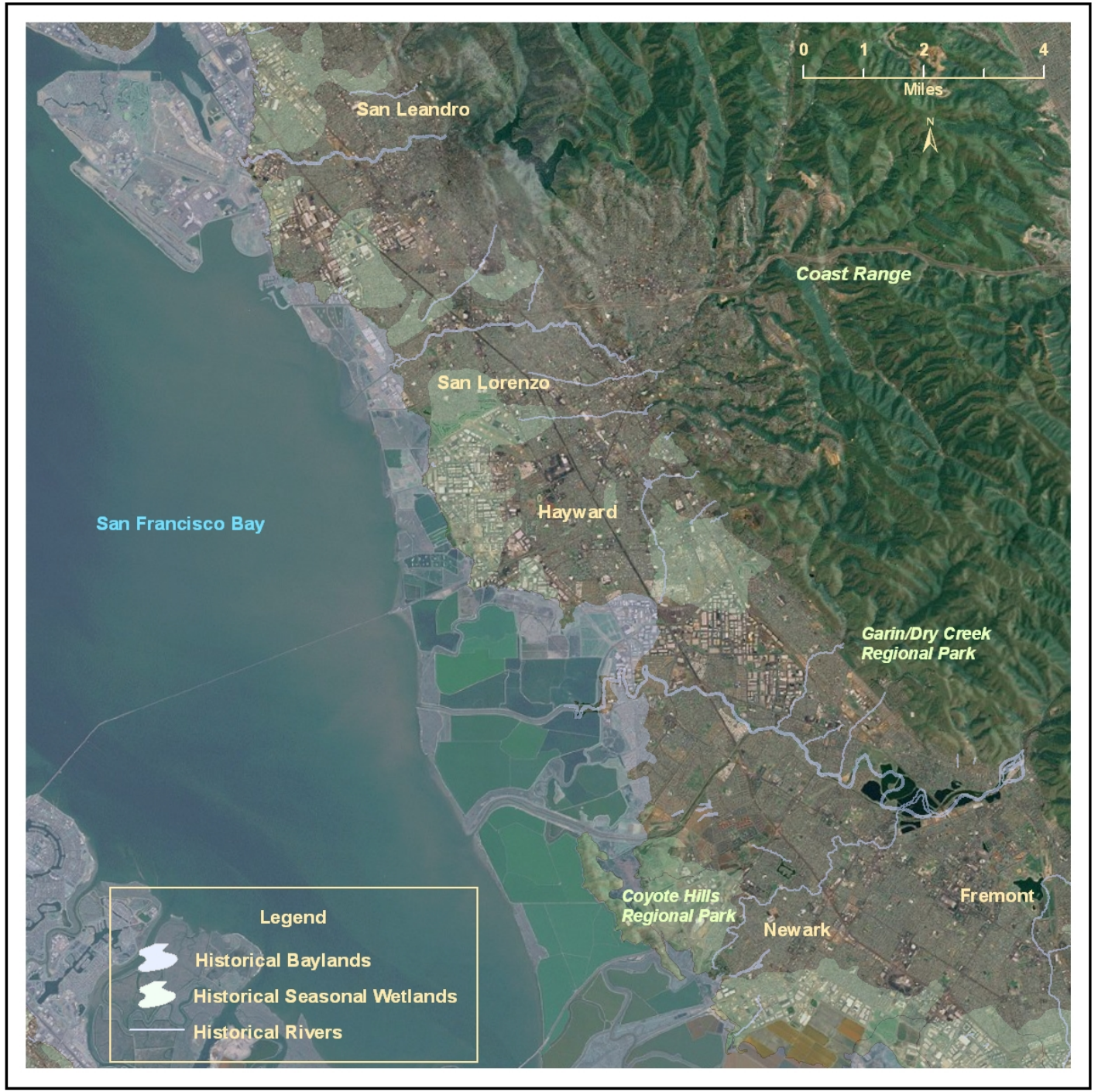

Created in ArcGIS by research author

Data courtesy of San Francisco Estuary Institute EcoAtlas

Figure 3. Past and present wetlands along the East Bay. Map created in ArcGIS by author. Data used with permission from San Francisco Estuary Institute (2000). 
Three types of sources were used for this project: translated versions of journals and diaries written before 1848 , native bee specimens collected before 1848 , and ethnobotanies of the Ohlone, both historical and present-day. The examination of multiple types of sources was necessary to improve the possibilities of finding data on native bees and to increase the level of confidence with the results. The dearth of pre-Gold Rush data on native bees necessitated the use of surrogate data—native pollen and nectar-producing plants - as a way to determine if native bees existed. The same date of 1848 and the same area of the East Bay were used when surrogate data were researched.

Journals and diaries were always kept by explorers and were also used by most missionaries to track successes and failures with settlement and conversion of Native Americans. These journals and diaries and the floral and faunal specimen collections were given to institutions on the East Coast or in Europe- the sponsors of these expeditions. A few journals and diaries of Spanish explorers and missionaries have been translated into English and were available for public reading. Only translated versions of journals and diaries of people who traveled specifically in the East Bay were researched.

Floral and faunal specimens were collected so taxonomists could analyze and identify new species without having to be in the field. The California Academy of Sciences, San Francisco, has one of the largest holdings of insect specimens in the country with an equally impressive number of California native bees available for public viewing (with permission). An online database of their insect collections, albeit not complete, was available and a visit was made to obtain specific location and date information. Entomology departments in out-of-state museums now have online databases, accessible 
via the Internet, which contain information on each specimen in their collections. Databases of the Smithsonian National Museum of Natural History, the American Museum of Natural Science, and the Canadian National Collection were accessed for native bee specimens because they contain the largest numbers of insect specimens in North America, if not the world.

If no specimens were located in these databases that met the date/place criteria, the databases of the Consortium of California Herbaria, the University of California/Jepson Herbarium Archives, Harvard University, and the Royal Botanic Gardens, Kew, England (often the recipient of specimens from the U.S. before the nineteenth century) were searched for native floral specimens. Initially, only place names in the Hayward Area were used within a specified date range, but due to a very limited number of specimens, the location was enlarged to include areas along the eastern and southern areas of San Francisco Bay.

The third source to be analyzed was ethnographies of the East Bay Ohlone tribe. The Ohlone have only an oral language so ethnographies written during the twentieth century were researched. Visits to two regional parks, sites of Ohlone land, were made to better understand how native flora and fauna were used in Ohlone everyday lives.

Uncertainty existed for each of the analyzed sources. However, the uncertainty levels were not so high as to disqualify the use of that particular source. Each results chapter (5-7) includes a discussion of uncertainty that surfaced from literature reviews and on-site experiences. 
Over the centuries, meanings of words have changed to reflect the contemporary culture. Specific environmental terms have become blurred in research as natural environments become more of a human-created landscape. For this project, the following words are defined as follows: Indigenous or Endemic - the species was found only within the stated area of California before the start of the eighteenth century and nowhere else. Native - the species existed in the San Francisco Bay Area as well as other parts of California before the start of the eighteenth century. Non-native-the species is native to parts of the United States but not found in present-day California. Exotic or Introduced - the species is from a country other than the United States. Wild-a native, non-native or exotic species that grows unaided by humans in rural areas. Naturalizedthe species is an exotic (or introduced) plant that has adapted and grows naturally on its own without any assistance from a human. Examples are the ubiquitous mustard (Brassica spp.) plant and the Eucalyptus tree (Eucalyptus spp.) species.

Native bees have specific foraging and habitat needs that would have been detrimentally impacted with the arrival of permanent European and American settlements. Conversely, many introduced plants could have been pollinated by native bees according to present-day studies of native bees foraging preferences. The next three chapters discuss the results and the uncertainties related to the results for each source: journals and diaries, bee and floral specimens, and Ohlone ethnographies. 


\section{Chapter 4: Background on Bees and San Francisco Bay Estuary}

The common honey bee (Apis mellifera) is the major pollinator for many horticultural and agricultural plants, native and exotic, in California. It is a European exotic bee species that arrived either in 1853 or late 1857 (Office of Historic Preservation, 2011; Horn, 2005, P. 96-97) via San Francisco, and played a pivotal role in the state's success with agriculture during the latter half of the nineteenth century. A credible resource has not been located that indicated sixteenth and seventeenth-century explorers brought honey bees on their explorations or eighteenth-century missionaries brought hives to pollinate the exotic vegetables and fruit trees that they planted. The lack of documentation supports the working assumption that honey bees were not present in the San Francisco Bay Area until the mid-nineteenth century. However, the question remains as to how agricultural plants were pollinated before the introduction of the honey bees.

The conductibility of native bee studies is a challenge due to the difficulty of 1) "tagging" a bee with a marker to track its whereabouts; 2) identifying species in midair because many species require a microscope to determine differences; and 3) finding nests and tracking foraging paths. Most California native bees do not nest in hives; each is solitary and nests in an existing hole, abandoned flower pots, in window sills or humanmade "bee boards." They create tunnels in soil, dead wood, or stems. The exception is the more social bumble bee that congregates with a few others in one tunnel. All bees need their nests near pollen or nectar-producing plants (Urban Bee Gardens, 2003c; Michener, 2007; Powell \& Hogue, 1979). 
California has a very large diversity of native bees because wild bee species prefer hotter and drier climates. Michener's (2007) studies showed that chaparral areas, such as the hills of the Coast Range in the East Bay, and the sparse woodland areas of the mountains in southern California have the largest diversity of bee species; desert areas are almost as diversified; the immediate coastal areas have the least number of speciesas much as $80 \%$ fewer (p. 102). Native bees have the ability to synchronize their emergence from the nest depending on the favorability of the season (Powell and Hogue, 1979; Michener, 2007). This adaptation suggests that drought conditions in California can postpone development of the native bee species anywhere in its lifecycle.

California's unique climate (dry summers and wet winters) impacts the seasonality of flora which impacts diversity, number, and concentration of native bees. Out-of-state collectors of the nineteenth and early-twentieth centuries searched for bee specimens during California's summer months when much of the native flora was not in bloom. The paucity of native bee specimens in museum collections is attributed to the poor timing of collectors (Powell and Hogue, 1979). As Powell and Hogue (1979) stated, California's topography is so diverse that a "complex mosaic of geographical, ecological, and seasonal niches to which insects [bees] have adapted" (p. 9) must be considered.

Native bee species forage both native and exotic flora as shown in studies by Kremen, Williams, Bugg, Fay, and Thorp (2004), Frankie, Thorp, Schindler, Hernandez, Ertter, and Rizzardi (2005), and Kim, Williams, and Kremen (2006). Their findings included: the closeness of natural and semi-natural habitat to pollen and nectar-producing flora improved the abundance of native bees; the availability of pollen/nectar-producing flora 
attracted a wider diversity of native bees and exotic bees; California native bees appeared to be less choosy than honey bees in the floral species that they foraged; and seasonality and location of flowering plants affected the diversity, presence, and concentration of native bees.

Dr. Gordon Frankie et al. (2005) conducted a multi-year survey of native and exotic bee species that visited urban gardens, with mostly exotic plants, in two north East Bay cities (Berkeley and Albany, north of Oakland). Seventy-two native and two exotic bee species visited these gardens. The researchers felt the native bee species were "probably limited to those species that historically occupied the area before urbanization" (p. 234) as these cities are located in areas that were grassland and oak woodland 250 years ago. California has 1,600 known species of bees of which only three are exotic according to Dr. Gordon Frankie on the Urban Bee Gardens website (Urban Bee Gardens, 2003b). This number of native species (see Figure 4 for one such native bee) includes species indigenous to particular regions within California and species found over a large region of California or found in California with ranges that extend beyond present-day California (political boundaries have no meaning to native bees). The colony collapse disorder of honey bees has prompted more research into the role(s) native bees play with California's agriculture so additional native species will likely be discovered. In 1979, 1,000 California native species were identified (Powell and Hogue, 1979, p. 344) whereas, in 2010, the number of species had increased to 1,600 (Urban Bee Gardens, 2003b). 


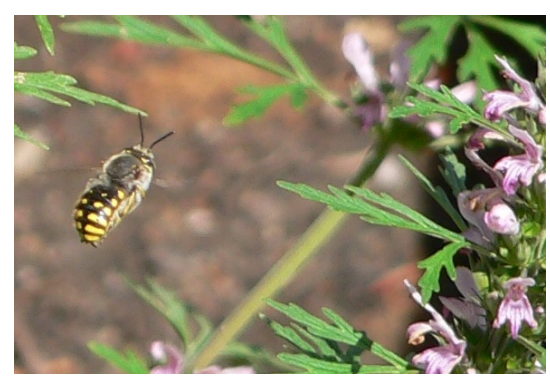

Figure 4. Native head-bonker bee (Anthidium maculosum) hovering near a Salvia (Salvia spp.) in author's Danville, California garden. Photograph taken by author, October, 2008.

The large numbers of native bee species surveyed in East Bay gardens indicate present-day environments support their foraging and habitat requirements. However, historical East Bay had larger expanses of wetlands that abutted the foothills, so native bee habitats, which require dry ground and materials, could not have existed in these areas (see Figure 3). Two-hundred-fifty years ago, San Francisco Bay was a larger estuary and even though approximately $95 \%$ of its wetlands no longer exist, San Francisco Bay is ecologically an estuary and not a bay. Grewell, Callaway, and Ferren (2007) defined an estuary as a coastal embayment receiving both ocean salt water and substantial freshwater flows, whereas a bay has no major freshwater inlets. Ocean tides and, to a lesser degree, currents move saltwater into San Francisco Bay, and freshwater enters from the Sacramento and San Joaquin Rivers (through the Delta) and smaller streams originating in the Coast Range. The southern reaches of the Bay have weaker and lower tides so salinity is higher, water temperatures are warmer, and the waters are more nutrient-rich (Grewell et al., 2007; McHugh, 2006). 
The portion of San Francisco Bay considered to be wetlands is described as "lands transitional between terrestrial and aquatic systems where the water table is usually at or near the surface or the land is covered by shallow water" (Grewell et al., 2007, p. 124) and dominated by vegetation. Marshlands and vegetated wetlands are interchangeable terms used in this thesis. The low marsh zone, dominated by cordgrass (Spartina foliosa) and salt marsh pickleweed (Sarcocornia pacifica), encounters most of the tidal flood changes but has the lowest salinity level in the marshlands; the mid marsh plain, dominated by salt marsh pickleweed (Sarcocornia pacifica) and marsh jaumea (Jaumea carnosa), encounters fewer tidal flood changes than the low marsh area, but the salinity level increases due to less water movement; and the high marsh zone, dominated by salt marsh pickleweed (Sarcocornia pacifica) and saltgrass (Distichlis spicata), has the highest salinity levels and the lowest tidal flood changes (Grewell et al., 2007). These marshlands are constantly affected by different levels of tides, freshwater fluctuations, and rough wind-driven waves (Hanson, 2000).

The historical wetlands were larger in size and reached further inland than today's wetlands. The earliest explorers and missionaries described springs, brooks, ponds, and lakes on present-day dry flatlands; large streams habitually overflowed their banks creating wide marshy valleys; estuaries supported tule marshes and extensive areas of pickleweed (Salicornia spp.) and cordgrass (Spartina foliosa); and the water table was higher than today (Margolin, 1978). As settlements became established, the ecosystems of the East Bay estuarine marshlands were being altered. Many small freshwater streams were covered or their flows diverted away from the estuary. Marshlands were diked for 
salt or drained for agriculture. By the mid-twentieth century, ports, military bases, landfills, sewage drainage systems, airports, and residential complexes were developed on filled-in marshlands (Hart and Sanger, 2003).

The estuarial ecosystems had supported and still support a diverse and abundant flora and fauna (see Figure 5 for a view of the estuary at Coyote Hills Regional Park) regardless of the multitude of changes. The estuary constantly changed which explained why estimates of estuary size and distance varied between explorer reports. Today, the remaining wetlands are being re-evaluated for their role and importance to the Bay's ecology and several restoration projects are underway in an effort to mitigate human alterations over the past 250 years.

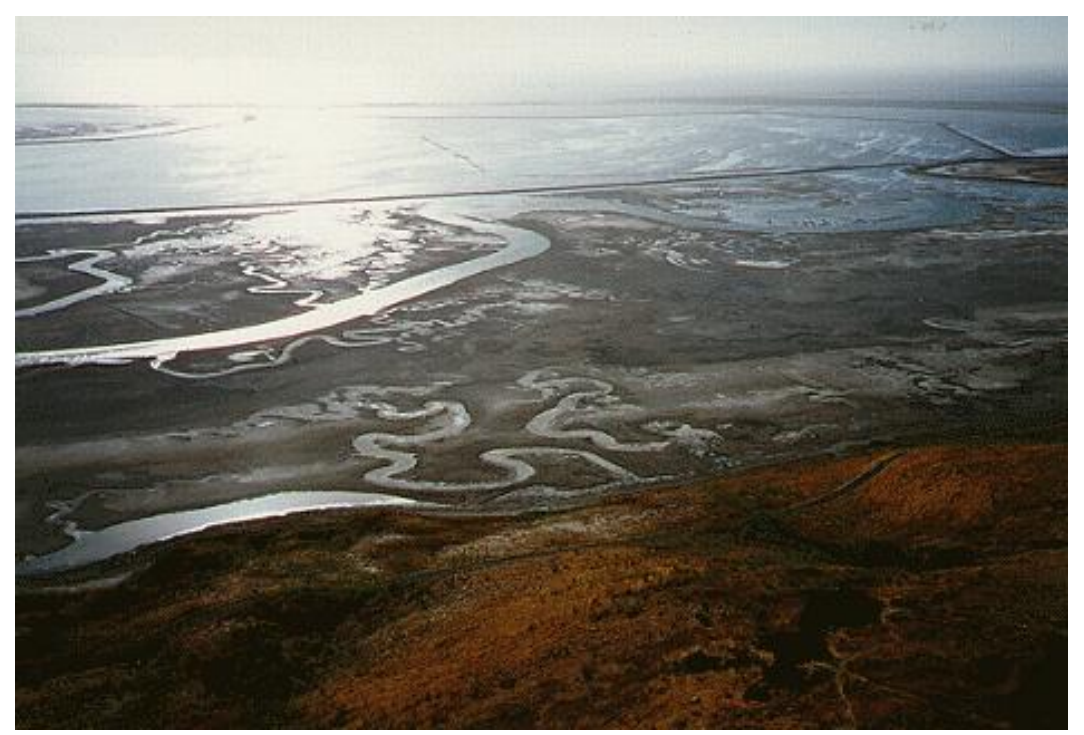

Figure 5. Looking across estuary in Coyote Hills Regional Park, northwest towards San Francisco Bay (Benton, 1996). Photograph taken by Charles C. Benton. Reprinted with permission from Charles C. Benton. 


\section{Chapter 5: Written and Visual Clues in Journals and Diaries}

The visible presence of English explorers during the early sixteenth century convinced the Spanish Crown to increase its explorations and to establish permanent settlements in California. Throughout the sixteenth century, several Spaniards explored California's coastline by ship, with land exploration in Baja California. The seriousness of claiming lands faltered until the mid-eighteenth century when land explorations extended beyond Baja California. By the latter part of the eighteenth century, missions had been established as far north as San Francisco. Journals and diaries of both Spanish explorers and missionaries of the San Francisco Bay Area such as Father Santa María (1775), Miguel Costansó (1769-1770), Father Pedro Font (1776), and Pedro Fages (1772) were researched for details of native flora and fauna.

The reading of journals/diaries written by Father Santa María, Miguel Costansó, Father Pedro Font, and Pedro Fages found no mention of bees. However, Miguel Costansó, as a member of Portolá's expedition in 1769-1770, wrote of eating cakes made of the "the honey of wasps" and wrapped in the "leaves of the carrizo cane" (Costansó, 1769/1992, p. 107). These sweets were provided to Portolá's men by the Native Americans near Año Nuevo, located on the coastline of central California.

Several reasons could explain the absence of bees (native or honey) in these journals and diaries. Bees are very small and therefore did not make an impression on newcomers as would a grizzly bear or a large herd of Tule elk. The missionaries brought honey bees with them to pollinate the imported fruit trees and vegetables, but written records of hives were lost. Native bees provided pollination but their solitary nature made them 
"invisible" to the missionaries. Honey bees were (and are) very well known in the United States, therefore English translators assumed honey bees were the pollinators instead of native bees, so stating the obvious was unnecessary. Lastly, the sweetness in Native American food was from a source other than honey but honey was assumed by the recipients.

The absences of bees in journals and diaries necessitated the search for surrogate data—native pollen and nectar-producing flora. Several explorers and missionaries mentioned seeing a variety of flora around San Francisco Bay, although names, common and botanical, were not provided because most of the flora was unfamiliar. A generic name such as "oak" or "poppy" was provided if the species looked familiar. Miguel Costansó mentioned seeing poplar and alder trees, white and live oaks, blackberries, and roses-all native to California—a few miles east of Monterey Bay, and in Half Moon Bay which is on the coast, near San Francisco (Costansó, 1769/1992). Soldier Pedro Fages explored the East Bay in the spring of 1770 and described seeing wildflowers, burned areas of grasses, and lush pastureland (Minnich, 2008).

Father Pedro Font, a member of the 1776 expedition led by Juan Bautista de Anza, wrote detailed notes of his travels along the western and eastern sides of the San Francisco Bay. He stated that the sloughs and tidal lands along the East Bay were impassable forcing the expedition to follow a road (more likely a path) near the base of the Coast Range (the foothills behind Hayward) where the area was "green and flowercovered all the way to the estuary, but with no other timber or firewood than that afforded by the trees in the arroyos which we encountered" (as cited in Beebe and Senkewicz, 
2001, p. 198). He also saw sycamores, live oaks, cottonwoods, and laurels (all native trees) growing near freshwater streams that emptied into the estuary. His observation that "a very thick grove of oaks and live oaks on the banks of the estuary, and is made into an island by two arms of the estuary" (as cited in Beebe and Senkewicz, 2001, p. 201), near present-day Alameda Island, indicated, surprisingly, that live oaks survived in brackish waters. His notes included distances between the foothills and the estuary's edge (shorter than today) and identified streams with groves of trees and canyons without shade (as cited in Beebe and Senkewicz, 2001). According to Minnich (2008), Font mentioned that wildflowers surrounded the road he traveled between San Jose and present-day Hayward Area (the month was March), and that local Native Americans ate onions, herbs, and grasses.

Father Pedro Font's diaries provided one of the earliest detailed descriptions of the East Bay; other missionaries kept detailed reports of their progress once the missions were established (Beebe and Senkewicz, 2001). All missions were secularized by the early 1830 s due to financial and political upheavals as the result of a newly independent Mexico. Consequently the missionaries had to leave, presumably taking their journals, diaries, and studies with them to either Mexico or Europe. An original journal or diary of a northern California missionary could provide clues, if not specific information, about farming practices and pollination activities. Missions were considered the center of importance; hence, few pueblos (towns) existed. However, the pueblo at San José persevered and by 1782 produced 2,000 bushels of corn (Beebe and Senkewicz, 2001, p. 277), indicating success at farming, although corn is wind, and not bee, pollinated. 
Explorations by naturalists and botanists were uncommon before California's Gold Rush, but the few who visited were in awe of California's wildlife diversity. Two of the earliest naturalists were J.F. Eschscholtz and Adelbert von Chamisso (both from presentday Estonia) who discovered the California poppy (Eschscholzia californica) in 1816 near the San Francisco Presidio (Beidleman, 2006). This flower is pollinated by several different native bee species. Eschscholtz returned to California in 1824 to enlarge his collections of plants and insects and conceivably his journals, field notes, and specimen collections are located in present-day Estonia.

Another enthusiast was Thomas Nuttall, an Englishman, a naturalist and professor at Harvard University, who collected extensively throughout the United States. He provided one of the first detailed descriptions of native flora when he visited present-day Monterey in 1836:

The forest trees were new to my view. A magpie [a new species]...chattered from the branches of an Oak with leaves like those of the Holly (Quercus agrifolia). A thorny Gooseberry, forming a small tree, appeared clad with pendulous flowers as brilliant as those of a Fuchsia [Ribes speciosum Pursh]. A new Plane tree [Platanus *racemosa] spread its wide arms over the dried up rivulets. A Ceanothus [thyrsiflorus Esch.], attaining the magnitude of a small tree, loaded with sky-blue withered flowers, lay on the rude wood-pile, consigned to the menial office of affording fuel...In this region The Olive and the Vine throve with luxuriance and teemed with fruit; the Prickly Pears (Cactus) became small trees, and the rare blooming Aloe (Agave americana) appeared consigned without care to the hedge row of the garden (Graustein, 1967, p. 314).

He also observed the California buckeye (Aesculus californica (Spach) Nutt.), white alder (Alnus rhombifolia), redberry buckthorn (Rhamnus crocea), ceanothus (Ceanothus), and manzanita (Arctostaphylos spp.) species (Graustein, 1967). Ceanothus, manzanita, and ribes are pollinated by native bees; however, Nuttall did not mention their presence. The 
areas around Monterey Bay and the East Bay share the same climate and growing zones (Brenzel, 2007), so the plants Nuttall observed would have been found in the East Bay foothills.

Eliza Farnham (1856) wrote how orchards of pears, apricots, and apples and vineyards flourished at Mission San José in 1851, fifty years after its establishment. Pears, apricots, and apples needed pollination by bees to flourish, but she did not mention the presence of any. Both Farnham (1856) and Bryant (1848/1985) mentioned the difficulty of walking their horses through thick fields of exotic but naturalized mustard (Brassica spp.) located between the town of San Jose and Mission Santa Clara. Mustard is pollinated by bees, but no mention of their presence was made by either writer even though hundreds of native or honey bees would have been foraging when the plants were in bloom. The absence of bees pervaded in journals and diaries published after the Gold Rush, implying that people did not consciously notice them or felt no need to write about them.

Each researched journal and diary had a level of uncertainty. The earliest observations of California were written in Spanish, therefore translation errors and abridged versions of diaries were often the reasons for incomplete or generalized accounts. According to Brown (1994), the owner of the Crespí journals prohibited the journals to be published in their entirety; hence the public version has only selected portions. Missionaries and presidio officers often altered their own original versions when presenting the official information to their superiors (Brown, 1994). Other causes for increased uncertainty included: illegible handwriting, loss of pages or sections over 
centuries of storage, language interpretation discrepancies (between Native Americans and Europeans, between Spanish and English, between speaker and listener/note taker), interpretation differences over centuries, biases of writers, and sharing of notes (Brown, 1994).

Minnich (2008) compared Brown's translated version of Crespí's diaries to Bolton's 1927 translation (considered the best at that time) and discovered Bolton had made considerable generalizations and incorrect assumptions about California's flora. Minnich (2008) made a strong argument that contemporary translators, unfamiliar with botany, assumed certain floral species when translating explorers and missionaries' diaries. Translators categorized wildflowers as native bunch grasses, and "pasture" and "sterile" were often interchanged. Unfortunately, Bolton's translation portrayed an inaccurate picture of California's flora for generations of readers and researchers.

Early Spanish explorers' primary interests, as reflected in their diaries, were the presence of other (i.e., indigenous) peoples, land cover, and suitable topography for a harbor, fort, and/or settlement. The missionaries' primary interests were the establishment of a church and environs acceptable to convert the indigenous people to Catholicism and Spanish way of life. California's natural environment was viewed, not for economic gain, but for its ability to provide a self-supporting settlement, so sketches of the environs were often present in journals and diaries. The sketches were later redrawn and published for the public. These visual images were created by people who had few materials and tools to accurately draw the image so scale and details are lacking. The images in Figure 6 were hand drawn during the late 1790s, most likely from ships. 
For the nineteenth-century viewer who had never seen California, these drawings provided him/her with a sense of place (and wonderment). However, analysis of these historical maps in today's environment was frustrating because the quality of the original was lacking due to either age or being a copy.
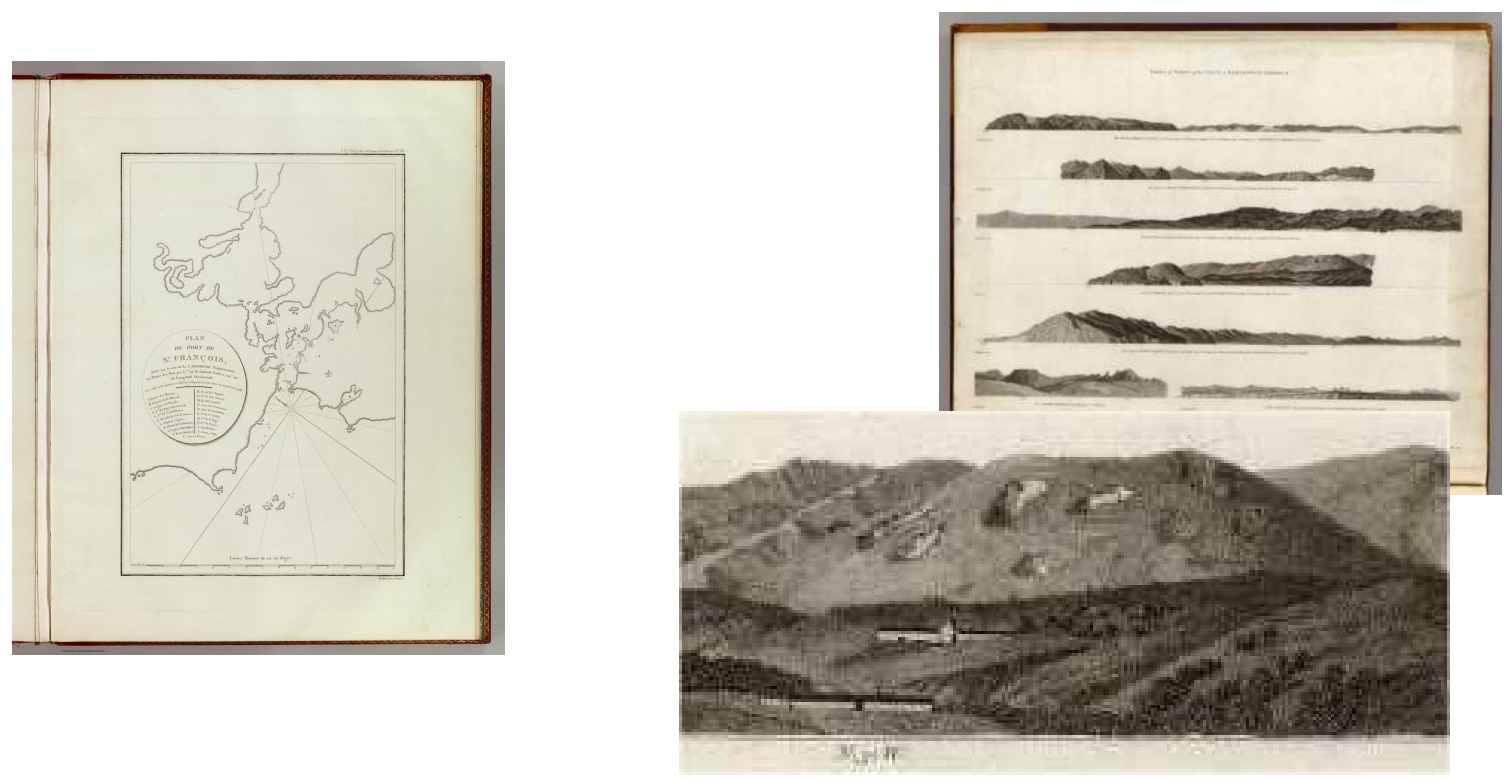

Figure 6. Visual media from the 1790s. (left) Engraving of Port de St. Francois (La Pérouse, 1797). (right) Hand drawing of Views of Parts of the Coast of North West America (Vancouver, 1798). The inset of the enlargement was done by author. Both images courtesy of David Rumsey Map Collection: Cartography Associates.

The map drawn by Jean François de Galaup, comte de La Pérouse in 1797 (see Figure 6, left) provided the spatial extent of San Francisco's Bay as well as its entrance from the sea-valuable information needed in order to claim the land for one's country. But topographic details were lacking. On the other hand, the drawings of the 1798 California coastline by Captain George Vancouver (see Figure 6, right) were detailed in technique and even though individual plants cannot be singled out, the viewer sensed that the 
environment was well vegetated. Individual plants can often be seen from faunal images, as seen in La Pérouse's 1797 drawing of quail (see Figure 7). The quail were the focal point for this image, but vegetation clues existed underneath the quails' feet.

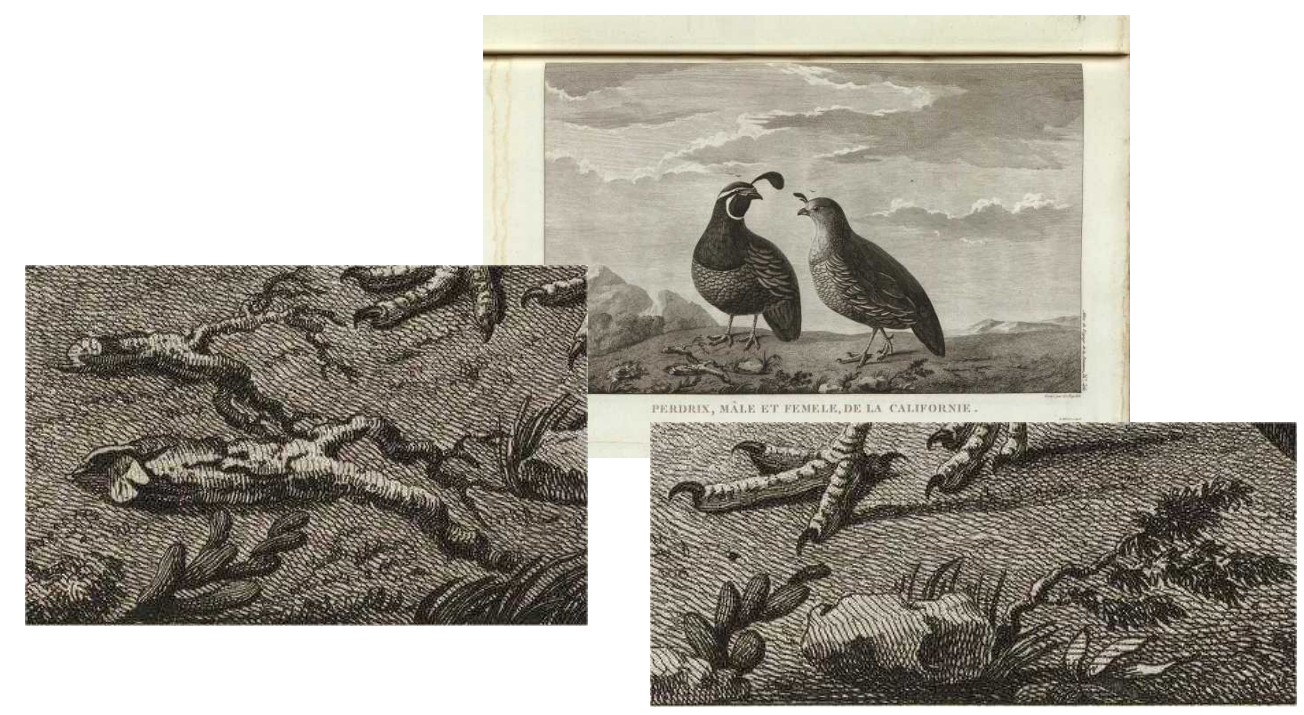

Figure 7. Engraving of Perdrix, male et female, de la Californie (La Pérouse, 1797). California quail. The enlarged pictures display the vegetation below the quail's feet. Images cropped and enlarged by author. Image courtesy of David Rumsey Map Collection: Cartography Associates.

A surprisingly large number of lithographs, engravings, and drawings were created before the Gold Rush although most images were of large scenic views. The vistas were sweeping expanses of the environment and provided the research author with a general idea of the topography and vegetation but with no details. A Remarkable Mountain near the River of Monterrey, as seen in Figure 8, provided enough detail to give the viewer a sense of grandeur, possible identification of the trees in the foreground and the overall impression that the land was well maintained. 


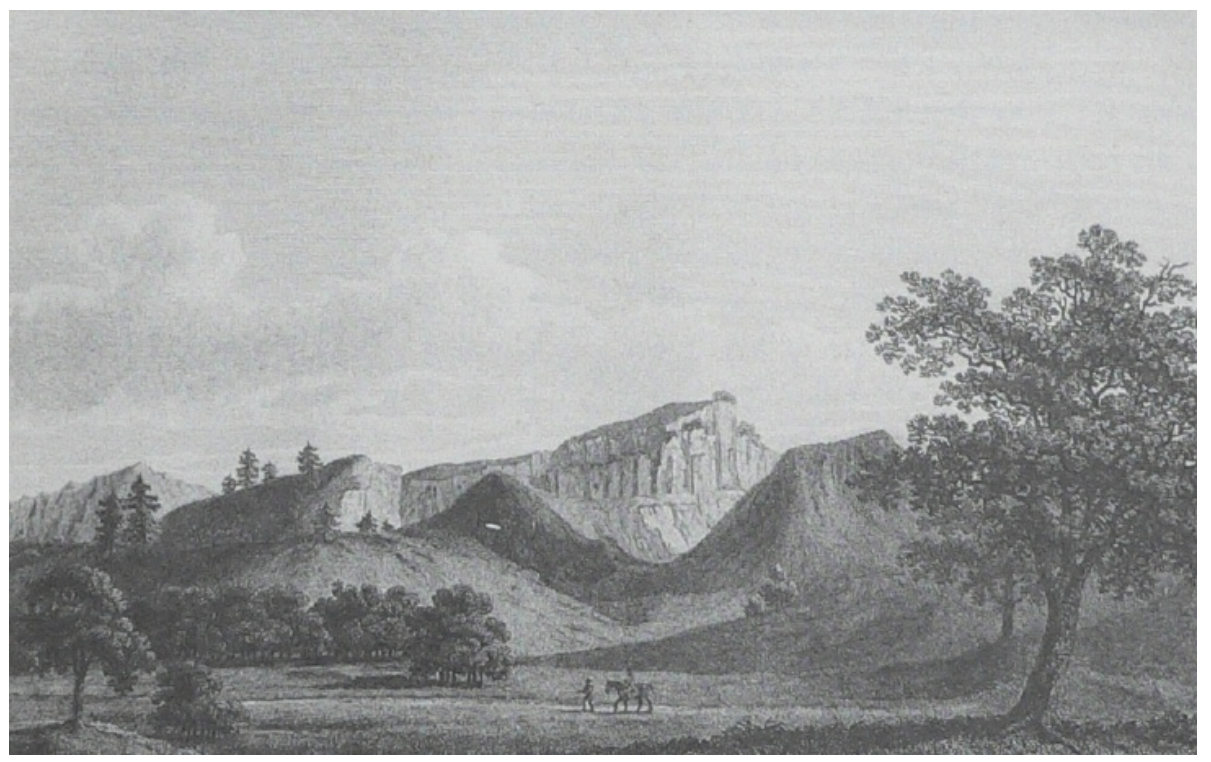

Figure 8. Engraving of A Remarkable Mountain near the River of Monterrey which portrays the 1790s landscape near Monterey Bay area (Anderson, Barbour, \&Whitworth, 1998, p. 15). Image courtesy of California Historical Society, FN-3052I.

Figures 9 and 10 provided two different versions of the San Francisco Bay Area leaving the impression that deforestation had taken place by the mid 1840s. In Figure 9 few trees were present around San Francisco and the hills across the bay appeared void of any vegetation except for a lone grove on one hilltop. The harbor was well protected, with ongoing trade, although wharfs were not depicted (a ship captain's log book may provide harbor details). The viewer would benefit from seeing this image in person as more details and color would provide a better idea of the natural surroundings. 


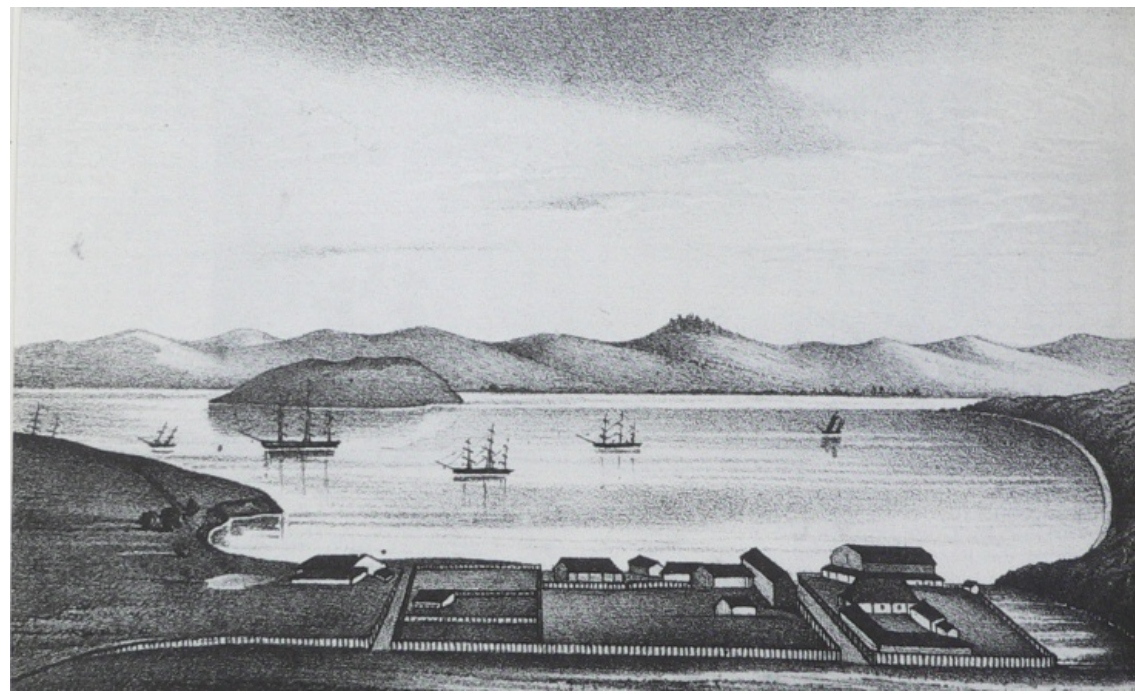

Figure 9. View of 1840s San Francisco, looking eastward across the San Francisco Bay (Robinson, 1846, facing p. 56).

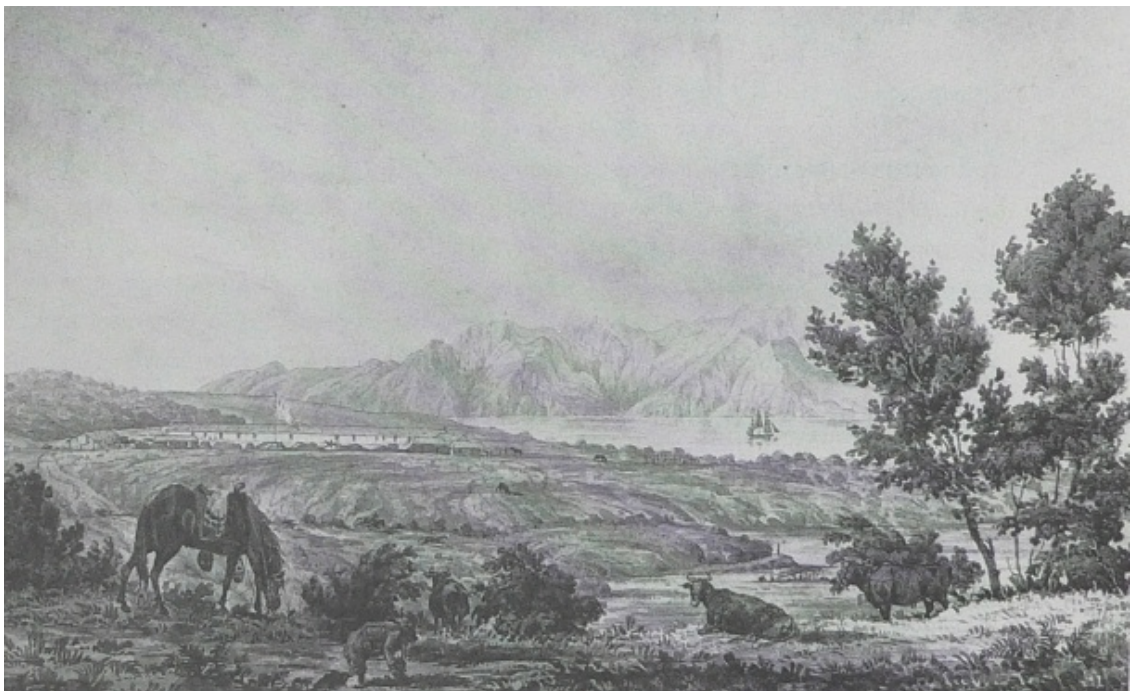

Figure 10. 1826 view of San Francisco Presidio (Anderson, Barbour, \&Whitworth, 1998, p. 13). Engraving courtesy Mr. and Mrs. Henry Dakin. Image used with permission from North Point Gallery. 
The image in Figure 10 was drawn fifteen years earlier, and displayed lush vegetation, good pastures, and steep rocky cliffs in the background. The vegetation in the foreground had enough detail to identify the genus if not the species of the vegetation. The artists' apparent perceptions of place were evident in these two images and a comparison of the two images showed the natural environment had changed.

Few images existed of the East Bay prior to the Gold Rush, but the image in Figure 11 was very informative because it portrayed local vegetation, the Ohlone, their textiles, boats and baskets, and the bay waters. The wilderness behind the Ohlone appeared to be chaparral-like vegetation found in the foothills of the East Bay but more details were needed to identify by species.

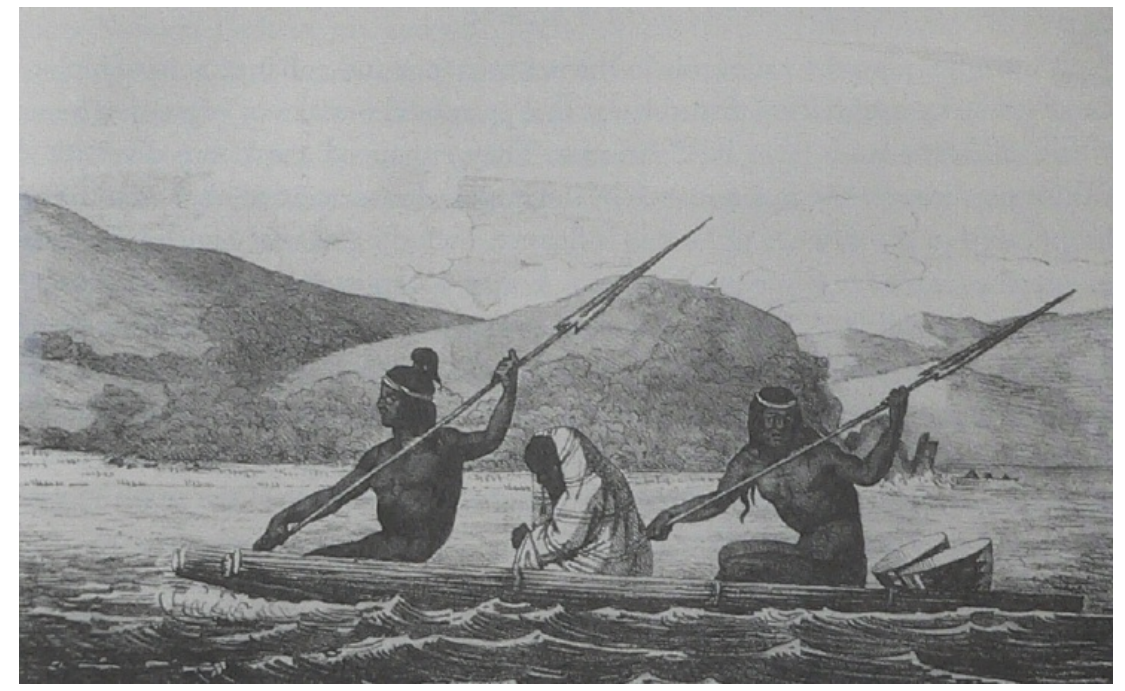

Figure 11. Lithograph of Ohlone paddling, based on a watercolor done in 1816 by Louis Choris from Voyage pittoresque autour du monde (Anderson, Barbour, \& Whitworth, 1998, p. 36). Image courtesy California Historical Society, FN-305I2.

The search for eighteenth and nineteenth-century images of both native bees and pollen-producing flowers specific to the East Bay produced no findings, so it was 
expanded to include areas around San Francisco Bay that shared the same climate and growing zones as the East Bay. One image was uncovered. The drawing (see Figure 12) on the left is naturalist Eschscholtz collecting California flora during an expedition in 1816 near the San Francisco Presidio or mission (Beidleman, 2006).
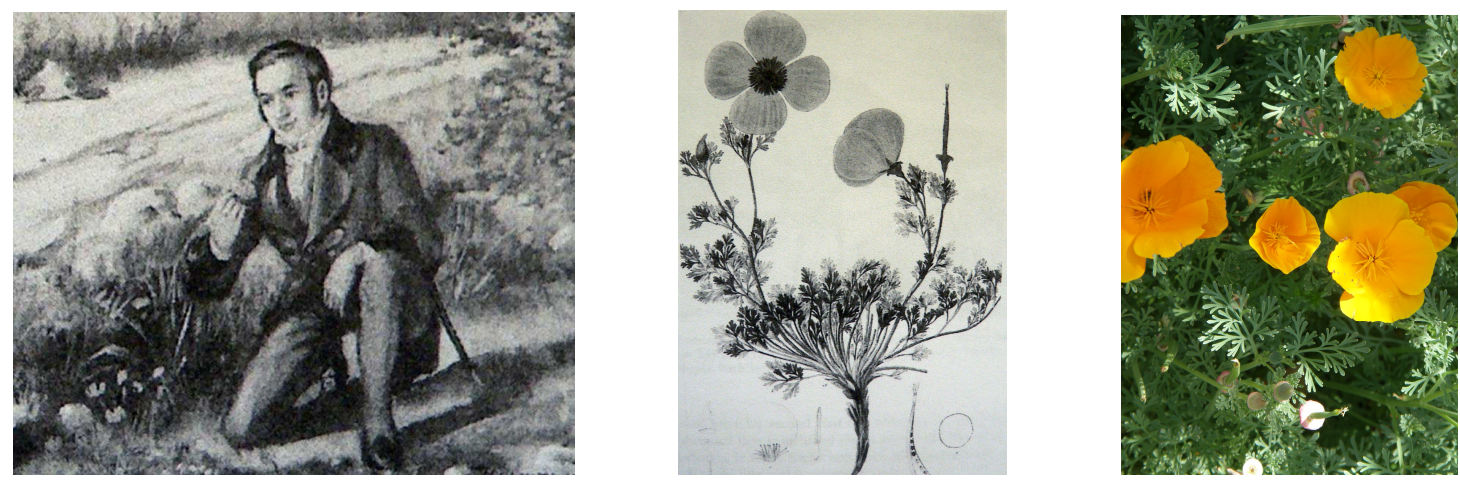

Figure 12. Drawing of and by 1800s naturalists, present-day photograph of a poppy. (left) Eschscholtz collecting flora in San Francisco Bay Area, 1816 (Beidleman, 2006, p. 52). Image cropped by author. Image courtesy of University and Jepson Herbaria, University of California, Berkeley. (middle) 1820 drawing by Friedrich Guimpel of a California poppy collected in 1816 (Beidleman, 2006, p. 54). Image from Horae Physicae Berolinensis, edited by C. G. Nees von Esenbeck, 1820. (right) Photograph of California poppies in author's garden, May, 2008.

The poppy, collected during Chamisso and Eschscholtz's explorations in 1816, was drawn in 1820 (see Figure 12, middle) after the poppy had been given its taxonomical name. Wildlife images were often drawn after identification, especially if the images were to be published (Beidleman, 2006). Next to the 1820 drawing of the poppy is a photograph of a California poppy growing in the research author's garden in Danville, California (see Figure 12, right). In comparison, the seed pods and the leaf shape are very similar and the number of petals is the same. However, the structure of the plant and the petal shape are different. The 1820 drawing would be closer to the original shape 
and structure of an indigenous California poppy as a hybrid plant with ruffle-edged petals grows amongst the research author's smooth-edged poppies.

The drawings of insects by José Guío, a member of Alejandro Malaspina’s 1791 Monterey Bay expedition, were the only pre-Gold Rush drawings of insects uncovered. The images were very detailed and in color (Beebe and Senkewicz, 2001) and likely generated great excitement in the entomology world. Research did not find any drawings of native bees from the East Bay or from the San Francisco Bay Area. Botanical drawings were not prevalent as most of the earliest explorers' field notes and drawings were shipped to either European institutions or to United States universities and museums on the East coast. Access to the original documents and images would minimize the uncertainties of a translated or copied version.

The appendix contains a list of those plants that were mentioned in this chapter as being from the East Bay before 1848. The discovery of the California poppy (Eschscholzia californica) in 1816, near the city of San Francisco, provided surrogate evidence that one native bee species existed 250 years ago in the San Francisco Bay Area because the poppy needs pollination by native bees (see Figure 13).
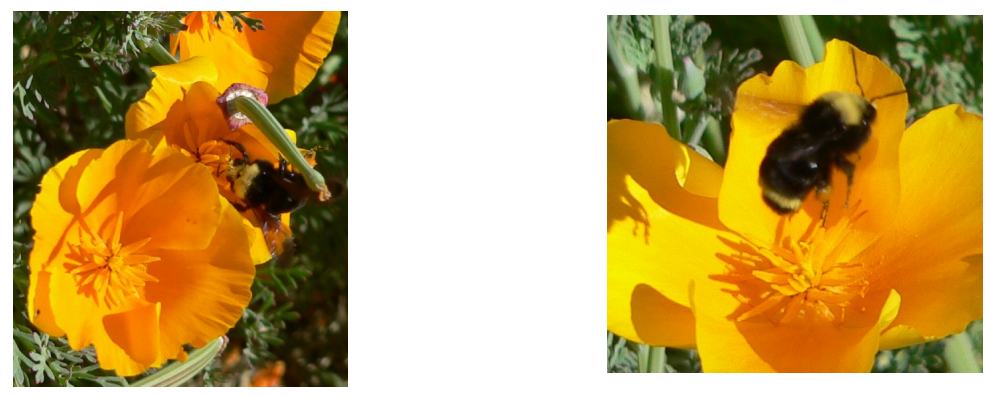

Figure 13: Bumble bees (Bombus spp.) on California poppy (Eschscholzia spp.) in author's garden. Photographs taken by author, June, 2008. 


\section{Chapter 6: Historical Native Bee and Plant Specimens}

Journals and diaries from the earliest explorations attracted the attention of countries interested in California's natural environment. Naturalists and botanists, sponsored by organizations excited to discover new flora and fauna, arrived by the late eighteenth and

early nineteenth centuries, to collect specimens. California's mild climates, dry seasons, and topographical diversity supported a vast variety of endemic species of flowers and insects (Powell and Hogue, 1979). The San Francisco Bay Area, including the East Bay, has dry summers and contains coastal scrub, chaparral, and foothill woodland environments, so the region had a "much larger proportion of [insect] species endemic to California" (Powell and Hogue, 1979, p.13 ) than other regions within California.

The California Academy of Sciences was founded in 1853; therefore insect specimens, specifically bees, collected in California before its establishment were transported to an institution on the East Coast or overseas to France, England, Prussia or Spain. By the second half of the nineteenth century, Asa Gray, John Torrey, and George Engelmann became the premier taxonomists in the United States (Beidleman, 2006;

Nilsson, 1994). Once the U. S. had well-known central repositories for flora and fauna, specimens and specimen collections were bought, exchanged, and donated to enhance their existing collections. Based on the sizes of their entomology collections, the entomology databases of the Smithsonian Institution National Museum of Natural History, the American Museum of Natural History, and the Canadian National Collection of Insects, Arachnids and Nematodes, in addition to the California Academy of Sciences, were searched for specimens of California native bees collected, but not necessarily 
classified and named, before 1848 . These particular institutions were chosen based on Harvard University's website listing institutions with larger collections than its own (Harvard University, 2010).

California Academy of Sciences' online database was researched for families of native bees identified by Powell and Hogue (1979): Andrenidae, Megachilidae, Halictidae, Anthophoridae, and Apidae. Frankie et al. (Urban Bee Gardens, 2003a) also tallied these five families of native bees in their research garden. California Academy of Sciences did not have any specimens of Andrenidae; all other families were represented. The database did not maintain a collection date and a more precise location within the county for each specimen, so an on-site visit was made to the Entomology Research Department to gather that information. The entomology collection had no native bee specimens collected before 1900 from Alameda County (county of research area). Table 1 provides a list of native bumble bee specimens collected after 1900 from towns in Alameda County. Interestingly, Bombus sitkensis was observed in 1848 (and, at a later time, was officially acknowledged as being a new species of bee) even though the specimens were collected after 1900 . Unfortunately the label attached to the specimen gave no indication where the bee was observed and could have been in a different region of California. The specimens in this table did not meet the two criteria of this research project: collected before 1848 and from the research area of Hayward, San Leandro or San Lorenzo. The search for specimens collected in Santa Clara, San Francisco, and Contra Costa counties was not done. 
Table 1

\section{On-site Tally of Bumble Bee Specimens at California Academy of Sciences for Alameda County}

\begin{tabular}{|c|c|c|c|c|c|}
\hline \multicolumn{6}{|c|}{ All specimens collected after 1900} \\
\hline Family & Genus & Species & $\begin{array}{c}\text { Year } \\
\text { Described }\end{array}$ & $\begin{array}{l}\text { Location Where } \\
\text { Specimen Found }\end{array}$ & \# of \\
\hline \multirow[t]{2}{*}{ Apidae } & Bombus & sitkensis & 1848 & Berkeley/Oakland & 2 \\
\hline & & & & Redwood park & 2 \\
\hline Apidae & Bombus & californicus & 1854 & Hills back of Oak & 1 \\
\hline \multirow[t]{3}{*}{ Apidae } & Bombus & terricola & 1858 & Albany & 1 \\
\hline & & & & $\begin{array}{l}\text { Berkeley/Oakland/ } \\
\text { Hills Oak. }\end{array}$ & 11 \\
\hline & & & & San Leandro & 1 \\
\hline \multirow[t]{4}{*}{ Apidae } & Bombus & vosnesenskii & 1862 & San Leandro & 1 \\
\hline & & & & Old Rifle Rd & 5 \\
\hline & & & & $\begin{array}{l}\text { Berkeley/Oakland/ } \\
\text { Hills Oak. }\end{array}$ & 3 \\
\hline & & & & Midway & 1 \\
\hline
\end{tabular}

Notes:

Year Described is the year the native bee was first described, not necessarily the year that the specimen was collected and not necessarily described when the collector was in California. Location is verbatim from label attached to specimen.

Since its inception, the Smithsonian National Museum of Natural Sciences was often the recipient of specimens collected in the U. S by other countries' collectors; its entomology collection of the Order Hymenoptera (bees belong to this order) has over 3,000,000 specimens according to its website. Its database allowed queries by country (United States), state (California), county the specimen was from, and ranges of collected dates. The counties queried were Contra Costa, Alameda, Santa Clara, and San Francisco. The data ranges used were: 1700-1848, 1848-1900, and 1900-1925. The 
same five families of bees were queried: Andrenidae, Megachilidae, Halictidae, Anthophoridae, and Apidae.

Smithsonian's database did not have any specimens from any of the four counties within the date ranges of 1700-1848 and 1848-1900. However, the date range of 19001925 (no county was identified) retrieved several specimens from various areas around San Francisco Bay. Specimens of the Andrenidae family were collected at Stanford University (in 1906, 1910, and 1915), Santa Clara (in 1913), San Francisco (in 1913), and Berkeley (in 1899). Specimens of the Apidae family were collected in Palo Alto (in 1904) and Berkeley (in 1915). Images were also available for many of the specimens, but the labels did not provide any relevant information.

Two additional institutions' databases were researched. The American Museum of Natural History had an interactive map, known as the Bee Database Project, with all of its specimens geo-referenced on a map of the world. Collection information was displayed when a symbol was clicked. A database accessible by the research author was not available. The map provided the research author with a sense of spatiality of specimen collections, but the San Francisco Bay Area specimens displayed were not collected before the mid-twentieth century. The Canadian National Collection website's overview stated $75-80 \%$ of their collections were on parasitic wasp groups so its database was not perused.

A search of each institution's online database saved time but key information, such as collected date or collected location, was lacking. An investigation of the specimens in their trays, although time consuming, was more beneficial. The institutions' websites 
stated their databases were incomplete due to high volumes of specimens and, in the case of the Smithsonian, images to record. Bees are very common insects, so the low numbers of specimens collected from the San Francisco Bay Area was likely a combination of many factors: native bees were in hibernation at times of collection; specimens were lost in transit; the conditions of specimens were poor so identification was not possible; specimens were marked "unidentified" (which was/is very common); and native bees did not exist in the research area at times of collection.

Unexpected issues with accuracy were encountered with the pinned specimens at the California Academy of Sciences. The span of time between the date a specimen was collected and the date it was taxonomically named (and sometimes re-named) meant numerous specimens of the same species had multiple names. Data on labels were not consistent across collections, handwriting on labels was difficult to read, generic topographic names were used for location, and a few towns no longer exist. All of the labels were paper, and some appeared to have been reused without the old information completely erased. A few discrepancies between the California Academy of Sciences' online database and the actual labels on the specimens impacted the results: the county where the specimen was collected stated "Alpine" in the database and "Alameda" on the label. The research author assumed that issues encountered with the specimens in California Academy of Sciences' entomology collection were also prevalent with other institutions' holdings.

Floral specimens, as surrogate data for the presence of native bees, were researched. The same criteria were used: collection date prior to 1848 and collection location of San 
Leandro, San Lorenzo or Hayward. The Consortium of California Herbaria maintains a database of floral specimens that are held in collections at 17 different institutions (University of California-Jepson Herbaria, California Academy of Sciences, California Department of Food and Agriculture, Santa Barbara Botanic Garden along with 12 other California institutions and the New York Botanical Garden). Access is provided by plant name, county, geographic locality, collector name or date range (the default state is "California"). Two hundred-eleven specimens were found that were collected before 1848. Of these, 14 were identified as being collected in and around the city of San Francisco and one was collected in Santa Clara. No specimens were found from locations in the East Bay. A valuable feature of this website was the geo-referenced map of specimens that displayed the more popular areas of collecting.

The database was then queried for plant specimens collected in the San Francisco Bay Area between 1848 and 1900 and 1,386 specimens were retrieved. The selection criteria were narrowed to the following towns: Hayward (2), Haywards (3), Eden (12), Washington (0), San Lorenzo (8), and San Leandro (44). The number in () indicates the number of specimens found: a total of 30 different floral species were retrieved and Calflora's website classified 22 of them as native. Seven specimens were exotic weeds and one specimen, collected in 1893 in the town of Mount Eden, is now thought to be extinct (Calflora). Many specimens were collected from areas other than the research area such as present-day Alameda and Oakland (north of the research area); of particular interest was specimens found in the saltier marshlands. Newark, Alvarado and Warm Springs (south of the research area) also had several specimens collected in the 1890 s. 
One of the premier nineteenth-century botanists, Thomas Nuttall, worked at Harvard University Herbaria so its database was researched for California specimens collected by him. No specimens were found. Dates, other than a published date, could not be entered; when "California" was entered as the locality, over 7,500 names of specimens were retrieved. Each record needed to be reviewed for when and where the specimen was collected. The database was more useful when the viewer knew of a particular collector or a particular publisher of flora-related publications.

The Royal Botanic Gardens, Kew, England, received centuries' worth of specimens from the world's explorers so its database was searched. The database was queried for "United States" in the country field; dates could not be entered. One thousand fourhundred eighty-seven specimens were retrieved; all with no state, county or city location. Three known botanists of California specimens were entered to narrow the results: David Douglas, Karl Theodor Hartweg, and Thomas Nuttall. The query on David Douglas, an avid collector of California's flora and fauna during the 1830s, retrieved 124 specimens. The details of each retrieved specimen did not mention a particular state within the U.S. However, more than two-thirds of the specimens included a photograph of the specimen along with the collector's original label and informational labels added by taxonomists, verifiers, and institution staff.

Douglas collected, in 1833, a specimen that was eventually named coastal blacksnakeroot (Sanicula laciniata). The database listed "United States" as the collected location, but the photograph of the specimen provided more definitive information. One label was typed "California Douglas 1833" and a note was signed by Hartweg in 
1848 with the handwritten "woods near Monterey". The Monterey Bay area has very similar climate and growing characteristics as the San Francisco Bay Area so this particular species could have grown in the Bay Area. Photographs of other specimens collected by Douglas did not contain additional information about where in the U.S. the specimen was collected. Investigation for the presence of additional labels on these photographs was useful, but disappointing because most photographs did not have applicable information.

Hartweg collected in 1845 and 1848 around Sacramento and the San Francisco Bay and Monterey Bay areas. The majority of the 57 specimens in the database had a collected date; the research author assumed specimens with no date were collected either in 1845 or 1848 . Photographs were reviewed and in a few cases, a collected date was available. Problems with illegible handwriting and confusing descriptions (example: "Dry sandy soils on the Columbia 1825" was written on the specimen collected near the "Bay of San Francisco" in 1848 increased the level of ambiguity. Thomas Nuttall made all of his discoveries before he returned to his native country of England in 1841. He was well-known for his collections of plants on the East Coast, but he traveled to California, specifically in the mid-1830s to collect. Kew's database did not have a collected date for his specimens and the labels on the photographs were illegible. However any specimen collected in California was before the Gold Rush; unfortunately, "California" was the only locality mentioned. A better understanding of his travels could provide educated assumptions of specific locations for his specimens. 
The search for floral specimens uncovered only one (see the Appendix) collected in the San Francisco Bay Area, but not in the East Bay, before the Gold Rush. Preservation of floral specimens was difficult at best, so the lack of specimens from the eighteenth and early-nineteenth centuries was not surprising. The following preservation instructions were provided to the nineteenth-century flora collector by George Engelmann of the Missouri Botanical Gardens:

'Collect if possible several specimens of the same plant, partly to show different shades of the same species, and partly to be able to distribute them among diff. botanist....It will be well to put your specimens in paper as soon as gathered; their parts are then fresh and still and are easily spread out in a neat way....After the specimen has been put in paper and pressed a while, it becomes necessary to change the layers of paper as soon as they have become damp from the moisture absorbed from the plant and to substitute dry ones for them. This ought to be repeated daily till the specimen is completely dried.... When you have got a sufficiently sized bundle together, pack it either in a box of convenient size or in a fresh skin of some animal (hair inside) which will harden and shrink and form an easily handled and safe package' (Nilsson, 1994, pp. ix-x).

Every preserved specimen did not reach its final destination. Many were destroyed during the expedition or lost at sea. Notes and seeds from La Pérouse's 1786 expedition, an expedition specifically sent to explore the natural sciences of the West Coast, arrived in Paris; the seeds of the California sand verbena (Abronia umbellata) were successfully grown in the French Botanical Garden. Unfortunately, all of the specimens collected from that particular expedition were lost when the ship sank at sea (Alden and Ifft, 1943). Many new discoveries were lost in the day and era when transportation was hindered by weather and rough terrain. Consequently, knowledge of California's historical indigenous flora and fauna has been detrimentally hampered. 
Other problems challenged historical collectors: wars interrupted funding, similar genera from China and Japan caused mislabeling, relevant notes and descriptions were misplaced, collector's ill heath impeded progress, and the expedition commander's disrespect for the work of the natural scientist meant fewer specimens were collected and shipped (Alden and Ifft, 1943). The lack of a central repository within the U.S. meant historical specimens were divided between multiple national and international institutions delaying identification for years. Specimens were lost within an institution or sat in trays as "unidentified" because the discoverer and location of discovery were never recorded.

Most pre-Gold Rush collectors were nationals from other countries. Johann Friedrich Gustav von Eschscholtz was from present-day Tartu, Estonia, when he and Adelbert von Chamisso discovered the California poppy in 1816. Sir Joseph Hooker (England), David Douglas (Scotland), Thomas Drummond (Scotland), Thomas Nuttall (England), William Brackenridge (Scotland), George Engelmann (Germany), Karl Theodor Hartweg (Germany), and Charles Christopher Parry (England) collected prodigious numbers of different species for their sponsors. Once reputations were established in the late nineteenth century by Americans such as Asa Gray at Harvard University and George Engelmann at the Missouri Botanical Garden, specimens of flora and fauna were sent to them in addition to the sponsors (Nilsson, 1994). Natural science explorations, west of the Rockies, was at its zenith by the late nineteenth century with hundreds of new species collected, preserved, and shipped for classification and naming.

Classification and naming involved several steps before new floral and fauna species were officially recognized. Each specimen was compared to known genera and species 
by looking at existing specimens or published descriptions of them. Next, multiple experts—locally, nationally, and internationally—collaborated with the analysis of the proper taxonomy. Thirdly, personal visits to other countries were often required to compare notes and resolve differences of opinions. New species from California created new genus and, occasionally, a new family required the taxonomy community to reevaluate existing families, genera, and species for proper reclassification, a process that continues today. These steps took years to accomplish and increased the likelihood of misplaced and lost specimens and erroneous and outdated information on labels.

The use of specimens was expected to provide a high degree of certainty, but a literature review revealed otherwise. Ross (1955) lamented that the quality of insect specimens differed between the collector who accumulated attractive-looking insects and the serious amateur who collected to increase entomological knowledge. The collector did not know basic anatomy or insect lifecycles, and oftentimes did not include geographical information. However, the large number of collectors and amateur entomologists led to the creation of entomological societies and the publication of respected periodicals thus improving specimen collection procedures and facilitating classification. Ponder, Carter, Flemons, and Chapman (2001) maintained that uncertainty was inherent with flora or fauna specimens because of the ad hoc nature of collecting, biases in the sampling, spatial and temporal gaps within a collection, having presenceonly data, and the popularity (or lack) of the genera often determined the quantity of individual species and the quality of specimens. 
For the research author, date and location information on labels caused the most confusion. The "year described" indicated when the description was provided. The species could have been seen in a state other than California if its present-day range spans neighboring states. "Year collected" or "collected date" indicated when the bee was caught as a specimen. "Year described" and "collected date" were often several years apart for a specimen. Frequently one or the other date was missing. The place of collection also proved to be problematic for multiple reasons. Before statehood, placenames were non-existed and political boundaries were fuzzy as settlers, rancheros/Californios, and Native Americans disputed boundary lines. Without definitive place-names, the collector had to use either the Native American name, the Spanish name or invent one; by the twentieth century many of the place names changed or the place disappeared. Alameda County was incorporated in 1853 so any specimen collected before this time may not have had "Alameda County" on its label.

The lack of specimens collected before the Gold Rush implied that native bees did not exist in the East Bay. Specimens, such as Bombus vosnesenskii and Bombus terricola, were collected after 1900 in San Leandro (part of the research area), suggesting that native bee territory was expanded by European-Americans. The limited number of floral specimens found in the institutions' databases was disappointing although not surprising. Most pre-Gold Rush collectors were from other countries; a few were from institutions on the East Coast. The collection of specimens was not an easy task and specimens frequently did not make the overland/overseas journey for identification. Lifecycles for native bees and native flora in California are intertwined and very dependent on dry 
summer and wet winter weather, quite the opposite of weather patterns encountered by those living east of the Sierra Nevada Mountains. A specimen-bee or flower-collected in the research area prior to the Gold Rush would certainly increase the level of certainty that at least one species of native bee inhabited the area before the influx of Gold Rush settlers. 


\section{Chapter 7: Bees and Plants Used by the Ohlone}

The Ohlone do not have a written history, so compilations of their oral histories were researched for references of bees and specific native flora. Two historical sites, located within regional parks, were visited; descendants of the Ohlone were not interviewed for this research. The Ohlone of pre-European contact utilized the native flora and fauna for food, clothing, shelter, medicine, and boat and basketry-making (Margolin, 1978) and

were "active agents of environmental change and stewardship" (Anderson, 2005, p. 2) as they burned patches of land to ensure the continuing growth of specific plants, and pruned and weeded to facilitate better growth (Anderson, 2005; Jacknis, 2004).

The presence of bees and related genera were mentioned in four contemporary cultural studies of California Native Americans. The Yokuts, inland foothill Native Americans, ate small amounts of honey produced by native bees (Jacknis, 2004) and Heizer and Elsasser (1980) commented that California Native Americans preferred native bee larvae over honey. The native bees referenced in these two documents may have been the native bumble bees (Bombus spp.) that are found statewide. Several bumble bee species produce very small amounts of honey required for the survival of their larvae (Thorp, Horning, \& Dunning, 1983), but these amounts are insignificant compared to the honey produced by honey bees. Anderson (2005) commented that yellowjacket (technically not a bee) nests were raided for the larvae and pupae and Margolin (1978) believed that the Ohlone numbed the adult yellowjackets in their nests with smoke and then dug out the grubs. The grubs were either boiled or roasted. 
John Peabody Harrington, an early twentieth-century ethnographer who studied the Ohlone for several decades, recorded an oral narrative called "Insects Take Revenge: The Man and the Wasps" from the descendants of the Native Americans at Mission San José (Ortiz, 1994). In the narrative, honey bees were smoked out of their hives and wasps were killed one by one by a being (referred to as "He" in the narrative which Ortiz interpreted as being a bear). No clues existed within the narrative as to location and timeframe of the setting, and Harrington's notes did not mention the age of the narrative (i. e. time immemorial or 50 years ago). According to Jacknis (2004) the Ohlone diets had already changed, necessary for their survival, by the time twentieth-century ethnographers began to record their lives. Ortiz, a contemporary ethnographer of California Native Americans and long-time researcher of the Ohlone, mentioned that the Ohlone typically adapted their narratives to current circumstances. Honey bees appeared in the Bay Area during the 1850s, so the bees mentioned in this oral narrative could have been honey, and not native, bees.

References to native flora were more plentiful, but none specifically stated the East Bay as their location. The Ohlone women collected seeds of sage (Salvia spp., Lepehinia,spp., and others), tansy mustard (Descurainia spp.), evening primrose (Camissonia spp., Oenothera spp.), clarkia (Clarkia spp.), madia (Centromadia spp., Madia spp., and others), and redmaid (Calandrinia spp.); they harvested clover (Castilleja spp., Trifolium spp., and others) and soaproot (Chlorogalum spp., Chenopodium spp.); and they gathered oak acorns (Quercus spp.) according to Margolin (1978). Anderson (2005) mentioned that the Ohlone in the San Francisco Bay Area dug 
up blue dicks (Dichelostemma capitatum) for food and rhizomes of various sedge species (Carex spp.) for basketry. Parkman (1994) noted that the Ohlone in the southeastern portion of the Bay Area relied heavily on acorns from oak trees (Quercus spp.), grasses such as bottlebrush or squirreltail (Elymus spp.), various brome species (Bromus spp.) and barley species (Hordeum spp.), and bulbs such as brodiaea (Brodiaea spp.).

The Garin/Dry Creek Pioneer Regional Park sponsored a hike/talk where the leader, Beverly Ortiz, explained how various native plants were used by the local eighteenthcentury Ohlone (Ortiz, 2008). The list of plants that were discussed is listed in the Appendix along with those discussed in the ethnographies. Garin/Dry Creek Pioneer Regional Park (see Figure 14) is situated in the foothills behind the city of Hayward and the plants discussed were believed to be present in the area (on a much larger scale) 250 years ago.

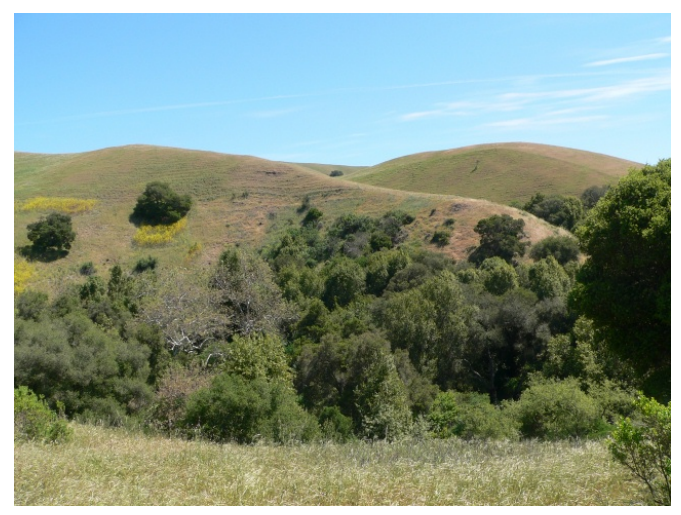

Figure 14. Hills in Garin/Dry Creek Regional Park, Hayward. Photograph taken by author, April, 2008.

Each generation of explorers, anthropologists, and ethnographers interpreted oral stories differently, hence all ethnographies have uncertainty (Ortiz, 1994). Ortiz's (1994) 
reading of Harrington's early twentieth-century notes emphasized where uncertainty was present. The lack of recording equipment meant notes were taken long-hand, so shorthand versions were used for words or sentences causing interpretation discrepancies. Interruptions due to questions and clarification of the story caused uneven flow of thought and difficulties with keeping the facts straight. She also noted that Harrington's interpretation of narratives differed from other people's interpretation of those same narratives. Ohlone oral histories primarily focused on events and consequences with timeframes and locations not mentioned, thereby creating confusion about dates and places.

Ethnographies of the Ohlone provided direct references to bees (and wasps) and important information on native flora, but they also contained uncertainties. Well-known anthropologists Alfred Kroeber and Harrington are highly respected ethnographers so a closer inspection of their works could uncover additional detailed information about the role native bees played in Ohlone lives. The native plants found in the Garin/Dry Creek Pioneer Regional Park confirmed that the Hayward Area, at least its foothills, supported pollen-producing plants foraged by native bees. The ethnographies provided clues to native bees and native flora, but as with journals, diaries, and specimens, no information specifically referenced the East Bay prior to the Gold Rush. 


\section{Chapter 8: Native Bees in Historical East Bay}

Two-hundred-fifty years ago, the East Bay was an indigenous landscape inhabited by the Yrgin and Tuibun Ohlone tribelets. The first Spanish explorers observed native vegetation that included large expanses of wildflowers. The landscape evolved from being indigenous to a combination of indigenous, native, and naturalized exotic plants once the missions became established. The ranchos contained a mixture of native and exotic plants; by the time of the Gold Rush, large sections of the East Bay were covered with grain and mustard fields.

Journals and diaries that were researched did not mention native bees regardless of the area. Specimens collected before 1848 did not exist for the research area (San Leandro, San Lorenzo, and Hayward) or other San Francisco Bay Area locations. Ohlone ethnographies mentioned bees, yellowjackets, and wasps, but no specific time or place was provided. Flora, as surrogate data, was not mentioned by name in journals and diaries. Not surprisingly, the majority of flora species could not be identified in-situ because these plants were new to the botanical world; specimens were taken for classification and naming. No specimens were collected before 1848 from the research area even though, according to Spanish explorers, wildflowers were present. Specimens of both native flora and bees were present in California Academy of Sciences and in other institutions' databases when the time frame was later than 1848 and the location was a more popular area such as Berkeley and San Francisco.

Various types of sources (within a specific timeframe) were used to increase the likelihood of finding data on native bees and to increase the reliability of that data. 
Observations of the same place at the same time were not possible because explorers, missionaries, rancheros/Californios, and botanists and naturalists arrived at different times, observed different flora and fauna from different vantage points and had different reasons for their explorations. One exception exists: Crespí and Fages were on the same exploration along the eastern shoreline of the East Bay and their notes were so similar that Brown (1994) felt their notes were shared with each other. Current translations of explorers and missionaries' written documentation have to be questioned as they were abridged from the original and Spanish to English translations have caused misinterpretations (Minnich, 2008). Additionally, references to bees required careful analysis. The lay person has a tendency to group yellow jackets, wasps, and native and honey bees under the category of "bees", but they are taxonomically separate genera. Consequently, this common mistake of grouping added a level of uncertainty when the word "bees" was generically used, especially when a differentiation between native and honey bees was important in this research.

The land cover in the East Bay, particularly in the Hayward Area, changed from a subtly managed natural environment to grain fields, orchards, and grazing land thus eliminating the original nesting areas and pollen and nectar-producing plants for native bees. On the other hand, new nesting sites became available when ditches, berms, and shoulders were created along field edges and bare earth was available between orchard trees and rows of vegetables. The introduced fruit trees and ornamental plants that replaced the indigenous land cover supplied foraging food. Contemporary studies by Kim et al. (2006) concluded that agriculture intensification affected most native bee 
species by destroying or eliminating nesting sites and materials even though floral vegetation had increased. However, the severity of the impact varied between species as each required different soil moisture, soil hardness, and nesting materials.

Native bees existed in the foothills of the Hayward Area foothills because pollen and nectar-producing plants were present according to Ortiz's (2008) research on Ohlone's uses of native plants. Crespí and Font's diaries mentioned wildflowers, many of which are pollinated by bees, growing in the research area's drier flatlands. Therefore, native bees must have been present even though they were not mentioned in any of the researched resources. These wildflowers were replaced with grain crops (typically not pollinated by bees), fruit trees (most are pollinated by bees), and mustard (pollinated by bees). Preston (1998) was correct when he stated that "the introduction of domesticated plants served partially to augment the floral diversity of the region at a time when other colonial agencies [groups of people] were reducing species diversity" (p. 285).

Margolin (1978) admitted that the Ohlone life described in his seminal book was "not so much about what Ohlone life was like, but rather about what Ohlone life may have been like" (p. 4). He pieced together oral stories, explorer and missionary diaries and journals, ethnographies and travelogues which, when combined, caused a certain degree of speculation and therefore uncertainty. Based on his admission, the presence of specific flora mentioned in his book, specifically in the estuarial flatlands, "may have been."

The missions, ranchos, and early European and American settlements did not eliminate native bees, but farming and grazing techniques impacted the diversity and 
concentration of species that survived. Present-day studies by Wojcik, Frankie, Thorp, and Hernandez (2008) showed that a greater diversity of flowers and the practice of pruning and dead-heading (removing dead blooms) allowed bees to extend their lifecycles. Pruning and dead-heading were practiced by the Ohlone (Anderson, 2005; Margolin, 1978) and by the missionaries and subsequent settlers because these activities increased production of fruit, vegetables, and flowers. This same study also noted that nearness of a natural or semi-natural environment improved the diversity and number of native bees. East Bay ecosystems were undergoing changes, but natural and semi-natural environments still existed in the nineteenth century as evidenced in lithographs in Thompson and West's (1878/1976) New Historical Atlas of Alameda Co. California.

California's present-day estuaries support dynamic and diverse wildlife even though the general public assumes wetlands to be lacking in flora and fauna. Grewell et al. (2007) listed 78 native plant species found in present-day San Francisco Bay's wetlands. A few of these estuarine plants are pollinated by bees, such as California sea lavender (Limonium californicum), common yarrow (Achillea millefolium), Pacific aster (Aster chilensis), gumweed (Grindelia stricta), and alkali heath (Frankenia salina). However, the role of insects, specifically native bees, is not well studied for an estuarine environment. As part of the Goals Project, Maffei (2000) discussed several faunal species, including five native bee species, which thrived in present-day San Francisco Bay wetlands. Whether or not these same bee species existed 250 years ago is not yet known, although Baye, Faber, and Grewell (2000) provided a partial answer. Baye et al. (2000) researched historical writings and references that described native plants growing 
in historical San Francisco Bay wetlands. The earliest reference mentioned in their research was from 1880, and a few plants such as California saltbush (Atriplex californica), flatface calico flower (Downingia pulchella), clustered goldenweed (Pyrrocoma racemosa), and Contra Costa goldfields (Lasthenia conjugens) were specifically identified as growing in the southern portions of the Bay's wetlands. Of the 55 species listed, at least two are pollinated by bees: flatface calico flower (Downingia pulchella), and Contra Costa goldfields (Lasthenia conjugens).

The Hayward Area was known as The Garden of Eden at the beginning of the twentieth century and native bees most likely aided in the area's success as an agricultural center. This research author found no conclusive written evidence of native bee existence in historical journals and diaries; no specimens-native bees or native flora-were collected in the research area before 1848; and no pre-1848 illustrations of native bees or flora in the research area existed. The Ohlone ethnographies were not conclusive.

The lack of quantitative evidence from 250 years ago suggests that native bees were not present, at least in noticeable numbers, in San Leandro, San Lorenzo, and Hayward. The historical foothills supported pollen-producing plants and suitable nesting sites and current studies indicated that pollen and nectar-producing flora existed in the historical wetlands. Based on contemporary studies by Maffei (2000) and Baye et al. (2000), this research author is confident that one species of native bees existed in and near the research area's historical wetlands before pre-European activity. European and American settlers impacted native bee habitats, but they did not exterminate them. The diversity of 
native bee species changed based on the local diversity of vegetation. Fewer pollen and nectar-producing plants meant fewer numbers of bees, not necessarily fewer different species. Native bee habitats changed, but did not disappear, and they likely increased with the increase of imported pollen and nectar-producing vegetation.
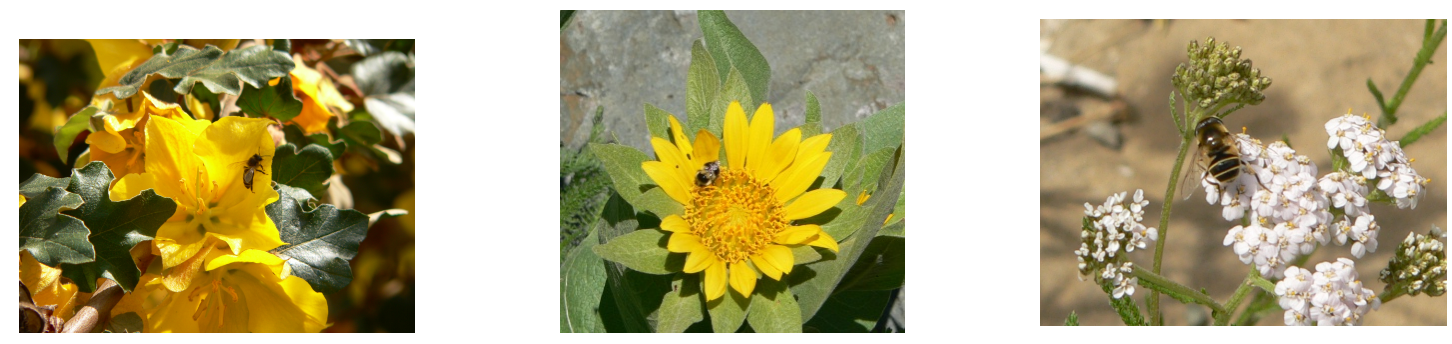

Figure 15. Native plants in author's garden (from left to right): Flannel bush, (Fremontodendron spp.); Mule's Ears (Wyethia spp.); Yarrow (Achillea spp.). Photographs taken by author, 2010. 


\section{References}

Alden, R. H. \& Ifft, J. D. (1943). Early naturalists in the Far West. In California Academy of Sciences Occasional papers no. 19-22 of the California Academy of Sciences. San Francisco, CA: California Academy of Sciences.

American Museum of Natural History. (2011). Invertebrate zoology: Bee database project. Retrieved from http://research.amnh.org/iz/bee-database-project

Anderson, M. K. (2005). Tending the wild: Native American knowledge and the management of California's natural resources. Berkeley: University of California Press.

Anderson, M. K., Barbour, M. G., \& Whitworth, V. (1998). A world of balance and plenty: Land, plants, animals, and humans in a pre-European California. In R. A. Gutiérrez, \& R. J. Orsi (Eds.), Contested Eden: California before the gold rush (pp. 12-47). Berkeley: University of California Press.

Baye, P., Faber, P. M., \& Grewell, B. (2000). Tidal marsh plants of the San Francisco Estuary. In Goals Project, Baylands ecosystem species and community profiles: Life histories and environmental requirements of key plants, fish and wildlife (pp. 9-32). Oakland, CA: San Francisco Bay Regional Water Quality Control Board.

Bean, L. J. (Ed.). (1994). The Ohlone past and present: Native Americans of the San Francisco Bay Region. Menlo Park, CA: Ballena Press.

Beebe, R. M., \& Senkewicz, R. M. (Eds.). (2001). Lands of promise and despair: Chronicles of early California, 1535-1846. Berkeley, CA: Heyday Books.

Beidleman, R. G. (2006). California's frontier naturalists. Berkeley: University of California Press.

Benton, C. C. (Photographer). (1996). Coyote Hills Regional Park [Photograph]. Retrieved March 21, 2011, from: http://arch.ced.berkeley.edu/kap/gallery/gal045.html

Brenzel, K. N. (Ed.). (2007). Sunset western garden book (8th ed.). Menlo Park, CA: Sunset Publishing Corp.

Brown, A. K. (1994). The European contact of 1772 and some later documentation. In L. J. Bean (Ed.), The Ohlone past and present: Native Americans of the San Francisco Bay region (pp. 1-39). Menlo Park, CA: Ballena Press.

Bryant, E. (1985). What I saw in California: Being the journal of a tour, by the immigrant route and south pass of the Rocky Mountains, across the continent of 
North America, the Great Desert Basin, and through California, in the years 1846, 1847. Lincoln: University of Nebraska Press. (Original work published in 1848).

Calflora. (n. d.). Information on wild California plants for conservation, education, and appreciation. Retrieved from http://www.calflora.org/

California Academy of Sciences. (2005). Entomology research general collection database. Retrieved from http://research.calacademy.org/research/entomology/EntInv/

Canadian National Collection. (2010). Hymenoptera: Collection. Retrieved from http://www.canacoll.org/Hymenoptera/Hymenoptera_Collection.htm

Consortium of California Herbaria. (2010). Data provided by the participants of the Consortium of California Herbaria (ucjeps.berkeley.edu/consortium/). Retrieved from http://ucjeps.berkeley.edu/consortium/

Costansó, M. (1992). The discovery of San Francisco Bay: The Portolá expedition of 1769-1770 (the diary of Miguel Costansó). (P. Browning, Ed.). Lafayette, CA: Great West Books. (Original work published in 1769).

Cronon, W. (2003). Changes in the land: Indians, colonists and the ecology of New England. New York, NY: Hill and Wang.

Farnham, E. W. (1856). California In-doors and out; Or how we farm, mine and live generally in the Golden State. New York, NY: Dix, Edwards \& Co.

Flores, D. (2001). The natural West: Environmental history in the Great Plains and Rocky Mountains. Norman: University of Oklahoma Press.

Frankie, G. W., Thorp, R. W., Schindler, M., Hernandez, J., Ertter, B., \& Rizzardi, M. (2005). Ecological patterns of bees and their host ornamental flowers in two northern California cities. Journal of the Kansas Entomological Society, 78(3), 227-246. doi:10.2317/0407.08.1

Galvin, J. (Ed.). (1971). The first Spanish entry into San Francisco Bay, 1775: The original narrative, hitherto unpublished, and further details by participants in the first explorations of the Bay's waters, together with four contemporary maps and six illustrations in full colour from the brush and pencil of Louis Choris who was at San Francisco in 1816. San Francisco, California: John Howell-Books.

Google Maps. (2011). Hayward Area. [Satellite map]. Retrieved from http://maps.google.com/maps?ie=UTF8\&rlz=1T4RNWE_enUS315US315\&hl=en\&tab=wl 
Graustein, J. E. (1967). Thomas Nuttall naturalist: Explorations in America 1808-1841. Cambridge, MA: Harvard University Press.

Grewell, B. J., Callaway, J. C., \& Ferren, W. R., Jr. (2007). Estuarine wetlands. In M. G. Barbour, T. Keeler-Wolf, \& A. A. Schoenherr (Eds.), Terrestrial vegetation of California (3rd ed.) (pp. 124-154). Berkeley: University of California Press.

Hackel, S. W. (1998). Land, labor, and production: the colonial economy of Spanish and Mexican California. In R. A. Gutiérrez, \& R. J. Orsi (Eds.), Contested Eden: California before the gold rush (pp. 111-146). Berkeley: University of California Press.

Hall, B., Motzkin, G., Foster, D. R., Syfert, M. \& Burk, J. (2002). Three hundred years of forest and land-use change in Massachusetts, USA. Journal of Biogeography, 29 (10/11), 1319-1335. doi:10.1046/j.1365-2699.2002.00790.x

Hanson, L. (2000). Plants of shallow subtidal habitat and tidal flats (with an emphasis on eelgrass). In Goals Project, Baylands ecosystem species and community profiles: Life histories and environmental requirements of key plants, fish and wildlife (pp. 1-8). Oakland, CA: San Francisco Bay Regional Water Quality Control Board.

Harlan, J. W. (1888). California '46 to '88. San Francisco, CA: The Bancroft Library.

Hart, J., \& Sanger, D. (2003). San Francisco Bay: Portrait of an estuary. Berkeley: University of California Press.

Harvard University. (2011). Harvard University: Museum of Comparative Zoology, Entomology Department Research Collections. Retrieved from http://www.mcz.harvard.edu/Departments/Entomology/holdings.html

Harvard University Herbaria. (2011). Harvard University Herbaria: Databases, Index of Botanists. Retrieved from http://kiki.huh.harvard.edu/databases/botanist_index.html

Heizer, R. F., \& Elsasser, A. B. (1980). The natural world of the California Indians. Berkeley: University of California Press.

Horn, T. (2005). Bees in America: How the honey bee shaped a nation. Lexington: The University Press of Kentucky.

Hornbeck, D. (1983). California patterns: A geographical and historical atlas. Palo Alto, CA: Mayfield Publishing Company.

Jacknis, I. (Ed.). (2004). Food in California Indian culture. Berkeley: Phoebe Hearst Museum of Anthropology, University of California. 
Kim, J., Williams, N., \& Kremen, C. (2006). Effects of cultivation and proximity to natural habitat on Ground-nesting native Bees in California sunflower fields. Journal of the Kansas Entomological Society 79(4), 309-320. doi:10.2317/0507.11.1

Klingle, M. (2007). Emerald city: An environmental history of Seattle. New Haven, CT: Yale University Press.

Kremen, C., Williams, N. M., Bugg, R. L., Fay, J. P., \& Thorp, R. W. (2004). The area requirements of an ecosystem service: crop pollination by native bee communities in California. Ecology Letters, 7(11), 1109-1119. doi:10.1111/j.1461-

0248.2004.00662.x

La Pérouse, Jean-François de Galaup, comte de (Artist). (1797). Perdrix, male et female, de la Californie. Dessine par Prevost. Grave par Le Pagelet. L. Aubert scripsit. Atlas du Voyage de la Perouse, no. 36. (Paris: L'Imprimerie de la Republique, An V, 1797). [Image of engraving]. Retrieved from http://www.davidrumsey.com/luna/servlet/detail/RUMSEY 8 1 20339 550036:Per drix,-male-et-femele,-de-la-

Cali?sort=Pub_List_No_InitialSort\&qvq=w4s:/where/California/when/1797/;sort:Pub _List_No_InitialSort;lc:RUMSEY 8 1\&mi=7\&trs=9

La Pérouse, Jean-François de Galaup, comte de (Artist). (1797). Plan du Port de St. François, situe sur la cote de la Californie Septentrionale. La Pointe des Rois par 37059' de latitude nord et 124054' de longitude occidentale. Atlas du Voyage de la Pérouse no. 33. (Au Depot General de la Marine en 1828). [Image of engraving]. Neptune des cotes occidentales d'Amerique sur le Grand Ocean. Retrieved from http://www.davidrumsey.com/luna/servlet/detail/RUMSEY 8 1 21248 610078:Pla n-du-Port-de-St--Francois,situe?sort=Pub_List_No_InitialSort\&qvq=w4s:/where/California/when/1797/;sort:Pu b_List_No_InitialSort;lc:RUMSEY 8 1\&mi=0\&trs $=9$

Leopold, A. (1966). A Sand County almanac with essays on conservation from Round River. New York, NY: Ballantine Books.

Maffei, W. (2000). A note on Invertebrate populations of the San Francisco Estuary. In Goals Project, Baylands ecosystem species and community profiles: Life histories and environmental requirements of key plants, fish and wildlife (pp. 184-192). Oakland, CA: San Francisco Bay Regional Water Quality Control Board.

Margolin, M. (1978). The Ohlone way: Indian life in the San Francisco-Monterey Bay Area. Berkeley, CA: Heyday Books. 
McCarthy, F. F. (1958). The history of Mission San José, California, 1797-1835. Fresno, CA: Academy Library Guild.

McHugh, P. (2006). Introduction. In J. A. Martin, \& M. T. Lee (Eds.), (2006). The islands of San Francisco Bay (pp. ii-iii). San Rafael, CA: Down Window Press.

Michener, C. D. (2007). The bees of the world (2nd ed.). Baltimore, MD: The Johns Hopkins University Press.

Minnich, R. A. (2008). California's fading wildflowers: Lost legacy and biological invasions. Berkeley: University of California Press.

Mount, J. F. (1995). California rivers and streams: The conflict between fluvial process and land use. Berkeley: University of California Press.

Nilsson, K. B. (1994). A wild flower by any other name: Sketches of pioneer naturalists who named our western plants. Yosemite National Park, CA: Yosemite Association.

Office of Historic Preservation: California State Parks. (2011). Santa Clara. Retrieved from http://www.parks.ca.gov/?page_id=21522

Ortiz, B. (2008, April). Ohlone plant foods. Naturalist hike and talk. Garin/Dry Creek Pioneer Regional Park, Hayward, CA.

Ortiz, B. R. (1994). Chocheño and Runsen narratives: A comparison. In L. J. Bean (Ed.), The Ohlone past and present: Native Americans of the San Francisco Bay region (pp. 99-163). Menlo Park, CA: Ballena Press.

Parkman, E. B. (1994). The bedrock milling station. In L. J. Bean (Ed.), The Ohlone past and present: Native Americans of the San Francisco Bay region (pp. 43-63). Menlo Park, CA: Ballena Press.

Ponder, W. F., Carter, G. A., Flemons, P., \& Chapman, R. R. (2001). Evaluation of museum collection data for use in biodiversity assessment. Conservation Biology, 15(30), 648-657. doi:10.1046/j.1523-1739.2001.015003648.x

Powell, J. A., \& Hogue, C. L. (1979). California Insects. Berkeley: University of California Press.

Preston, W. (1998). Serpent in the garden: environmental change in colonial California. In R. A. Gutiérrez, \& R. J. Orsi (Eds.), Contested Eden: California before the gold rush (pp. 260-298). Berkeley: University of California Press. 
Rawls, J. J., \& Bean, W. (1998). California: An interpretive history (7th ed.). Boston, MA: McGraw-Hill.

Robinson, A. (1846). Life in California during a residence of several years in that territory, comprising a description of the country and the missionary establishments, with incidents, observations, etc., etc., illustrated with numerous engravings. By an American, to which is annexed a historical account of the origin, customs, and traditions of the Indians of Alta-California. Translated from the original Spanish manuscript. New York, NY: Wiley and Putnam.

Ross, E. S. (1955). Systematic entomology. In California Academy of Sciences, $A$ century of progress in the natural sciences, 1853-1953 (pp. 485-495). San Francisco, CA: California Academy of Sciences.

Royal Botanic Gardens: Kew Herbarium Collections. (n. d.). Welcome to the Kew Herbarium Catalogue. Retrieved from http://apps.kew.org/herbcat/navigator.do

San Francisco Estuary Institute. (2000). EcoAtlas. Retrieved from http://www.ecoatlas.org/EcoAtlas/mapviewer.jsf?width=949\&height=691

Smithsonian National Museum of Natural History. (2011). Search the Department of Entomology Collections. Retrieved from http://collections.nmnh.si.edu/search/ento/

Soulé, F., Gihon, J. H., M. D., \& Nisbet, J. (1855). The annals of San Francisco; containing a summary of the history of the first discovery, settlement, progress, and present condition of California, and a complete history of all the important events connected with its great city: To which are added, biographical memoirs of some prominent citizens. New York, NY: D. Appleton \& Company.

Thompson and West. (1878). New historical atlas of Alameda Co. California. Oakland, CA: Thompson and West. (Reprinted in 1976 by Valley Publishers, Fresno, California).

Thorp, R. W., Horning, D. S., \& Dunning, L. L. (1983). Bumble bees and cuckoo bumble bees of California (Hymenoptera: Apidae). Retrieved from http://essig.berkeley.edu/documents/cis/cis23.pdf

Urban Bee Gardens. (2003a). Flowering plant species and their relative attraction to honey bees and native California bees in Albany and N. Berkeley. Retrieved from http://nature.berkeley.edu/urbanbeegardens/docs/FullPlantList.pdf

Urban Bee Gardens. (2003b). Bees: the world's star pollinators. Retrieved from http://nature.berkeley.edu/urbanbeegardens/ 
Urban Bee Gardens. (2003c). Where do bees nest in the city? Retrieved from http://nature.berkeley.edu/urbanbeegardens/list.html

Vallejo, M. G., (2001). The arrival of a North American wagon train. In R. M. Beebe \& R. M. Senkewicz (Eds.), Lands of promise and despair: chronicles of early California, 1535-1846 (pp 423-427). Berkeley, CA: Heyday Books. (Original work written in 1841).

Vancouver, George (Artist). (1798). Views of parts of the coast of North West America [Image of sketch]. A voyage of discovery to the North Pacific Ocean and round the world in which the coast of North-West America has been carefully examined and accurately surveyed. Undertaken by His Majesty's Command, principally with a view to ascertain the existence of any navigable communication between the North Pacific and North Atlantic Oceans; And performed in the years 1790, 1791, 1792, 1793, 1794, and 1795 in the Discovery Sloop Of War, and armed tender Chatham, under the command of Captain George Vancouver. In three volumes. London: Printed for G.G. And J. Robinson, Paternoster-Row; And J. Edwards, Pall-Mall. 1798. Retrieved from http://www.davidrumsey.com/luna/servlet/detail/RUMSEY 8 1 2281 200024:View s-of-Parts-of-the-Coast-of-

Nort?sort=Pub_List_No_InitialSort\&qvq=w4s:/where/California/when/1798/;sort:Pu b_List_No_InitialSort;lc:RUMSEY 8 1\&mi=3\&trs $=4$

Wojcik, V. A., Frankie, G. W., Thorp, R. W., \& Hernandez, J. L. (2008). Seasonality in bees and their floral resource plants at a constructed urban bee habitat in Berkeley, California. Journal of the Kansas Entomological Society 81(1), 15-28. doi:10.2317/JKES-701.17.1 


\section{Appendix: Presence of Vegetation in pre-Gold Rush East Bay}

Note: The ' $\checkmark$ ' indicates which source mentioned the plant.

The '*' denotes a plant that is bee pollinated.

\begin{tabular}{|c|c|c|c|c|c|c|}
\hline $\begin{array}{l}\text { Common } \\
\text { Name }\end{array}$ & $\begin{array}{l}\mathrm{B} \\
\mathrm{P}\end{array}$ & $\begin{array}{l}\text { Scientific } \\
\text { Name }\end{array}$ & $\begin{array}{l}\text { Journals, } \\
\text { Diaries, } \\
\text { Images }\end{array}$ & Specimens & $\begin{array}{l}\text { Ohlone } \\
\text { ethno- } \\
\text { graphies }\end{array}$ & $\begin{array}{l}\text { Visits to } \\
\text { Regional } \\
\text { Parks }\end{array}$ \\
\hline $\begin{array}{l}\text { Apples } \\
\text { (non-native) }\end{array}$ & * & Malus domesica & $\checkmark$ & & & \\
\hline $\begin{array}{l}\text { Apricots } \\
\text { (non-native) }\end{array}$ & $*$ & $\begin{array}{l}\text { Prunus } \\
\text { armeniaca }\end{array}$ & $\checkmark$ & & & \\
\hline Barley & $*$ & Hordeum spp. & & & $\checkmark$ & \\
\hline Black oak & & $\begin{array}{l}\text { Quercus } \\
\text { kelloggii }\end{array}$ & & & & $\checkmark$ \\
\hline Blue Dicks & & $\begin{array}{l}\text { Dichelostemma } \\
\text { capitatum }\end{array}$ & & & $\checkmark$ & \\
\hline Blue witch & $*$ & $\begin{array}{l}\text { Solanum } \\
\text { umbelliferum }\end{array}$ & & & & $\checkmark$ \\
\hline $\begin{array}{l}\text { Bottlebrush } \\
\text { or Squirreltail }\end{array}$ & & $\begin{array}{l}\text { Elymus } \\
\text { elymoides }\end{array}$ & & & $\checkmark$ & \\
\hline Brodiaea & & Brodiaea spp. & & & $\checkmark$ & $\checkmark$ \\
\hline Brome & & Bromus spp. & & & $\checkmark$ & \\
\hline Buttercups & $*$ & $\begin{array}{l}\text { Ranunculus } \\
\text { spp. }\end{array}$ & & & & $\checkmark$ \\
\hline $\begin{array}{l}\text { California } \\
\text { bay }\end{array}$ & $*$ & $\begin{array}{l}\text { Umbellularia } \\
\text { californica }\end{array}$ & & & & $\checkmark$ \\
\hline $\begin{array}{l}\text { California } \\
\text { poppy }\end{array}$ & * & $\begin{array}{l}\text { Eschscholzia } \\
\text { californica }\end{array}$ & $\begin{array}{c}\text { San } \\
\text { Francisco } \\
\text { Area }\end{array}$ & & & $\checkmark$ \\
\hline
\end{tabular}




\begin{tabular}{|c|c|c|c|c|c|c|}
\hline $\begin{array}{l}\text { Common } \\
\text { Name }\end{array}$ & $\begin{array}{l}\mathrm{B} \\
\mathrm{P}\end{array}$ & $\begin{array}{l}\text { Scientific } \\
\text { Name }\end{array}$ & $\begin{array}{l}\text { Journals, } \\
\text { Diaries, } \\
\text { Images }\end{array}$ & Specimens & $\begin{array}{l}\text { Ohlone } \\
\text { ethno- } \\
\text { graphies }\end{array}$ & $\begin{array}{l}\text { Visits to } \\
\text { Regional } \\
\text { Parks }\end{array}$ \\
\hline Clarkia & $*$ & Clarkia spp. & & & $\checkmark$ & \\
\hline Clover & $*$ & $\begin{array}{l}\text { Castilleja spp., } \\
\text { Trifolium spp. }\end{array}$ & & & $\checkmark$ & \\
\hline $\begin{array}{l}\text { Coast Live } \\
\text { Oak }\end{array}$ & & $\begin{array}{l}\text { Quercus } \\
\text { agrifolia }\end{array}$ & $\checkmark$ & & & \\
\hline Cordgrass & & Spatina spp. & & & $\checkmark$ & \\
\hline Corn & & Zea mays & $\checkmark$ & & & \\
\hline Cottonwood & $*$ & Populus spp. & $\checkmark$ & & & \\
\hline Dogbane & $*$ & $\begin{array}{l}\text { Apocynum spp., } \\
\text { Cycladenia spp. }\end{array}$ & & & & $\checkmark$ \\
\hline Elderberry & $*$ & Sambucus spp. & & & & $\checkmark$ \\
\hline $\begin{array}{l}\text { Evening } \\
\text { Primrose }\end{array}$ & $*$ & $\begin{array}{l}\text { Camissonia } \\
\text { spp., } \\
\text { Oenothera spp. }\end{array}$ & & & $\checkmark$ & \\
\hline Grasses & - & 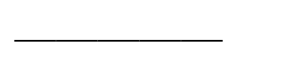 & $\checkmark$ & & & \\
\hline $\begin{array}{l}\text { Hayfield } \\
\text { Tarweed }\end{array}$ & $*$ & $\begin{array}{l}\text { Hemizonia } \\
\text { congesta }\end{array}$ & & $\begin{array}{l}\text { Santa Clara } \\
\text { County }\end{array}$ & & \\
\hline Herbs & - & - & $\checkmark$ & & & \\
\hline $\begin{array}{l}\text { Island Scrub } \\
\text { Oak }\end{array}$ & $?$ & $\begin{array}{l}\text { Quercus } \\
\text { parvula }\end{array}$ & & & & $\checkmark$ \\
\hline Laurel & $*$ & $\begin{array}{l}\text { Kalmia spp., } \\
\text { Malosma spp. }\end{array}$ & $\checkmark$ & & & \\
\hline
\end{tabular}




\begin{tabular}{|c|c|c|c|c|c|c|}
\hline $\begin{array}{l}\text { Common } \\
\text { Name }\end{array}$ & $\begin{array}{l}\mathrm{B} \\
\mathrm{P}\end{array}$ & $\begin{array}{l}\text { Scientific } \\
\text { Name }\end{array}$ & $\begin{array}{l}\text { Journals, } \\
\text { Diaries, } \\
\text { Images }\end{array}$ & Specimens & $\begin{array}{l}\text { Ohlone } \\
\text { ethno- } \\
\text { graphies }\end{array}$ & $\begin{array}{l}\text { Visits to } \\
\text { Regional } \\
\text { Parks }\end{array}$ \\
\hline Madia & $*$ & $\begin{array}{l}\text { Centromadia } \\
\text { spp., } \\
\text { Madia spp. }\end{array}$ & & & $\checkmark$ & \\
\hline Milkweed & * & Asclepias spp. & & & & $\checkmark$ \\
\hline $\begin{array}{l}\text { Miners' } \\
\text { lettuce }\end{array}$ & & Montia spp. & & & $\checkmark$ & \\
\hline Mule's ears & $*$ & Wyethia spp. & & & & $\checkmark$ \\
\hline $\begin{array}{l}\text { Mustard } \\
\text { (non-native) }\end{array}$ & $*$ & $\begin{array}{l}\text { Brassica spp. } \\
\text { Arabis spp. }\end{array}$ & $\checkmark$ & & & \\
\hline Nettle & $*$ & Stachys spp. & & & & $\checkmark$ \\
\hline $\begin{array}{l}\text { Oaks (no } \\
\text { specific species) }\end{array}$ & ? & Quercus spp. & & & $\checkmark$ & \\
\hline Onions & $*$ & Alliums spp. & $\checkmark$ & & & \\
\hline $\begin{array}{l}\text { Pears } \\
\text { (non-native) }\end{array}$ & $*$ & $\begin{array}{l}\text { Pyrus } \\
\text { communis (?) }\end{array}$ & $\checkmark$ & & & \\
\hline Pickleweed & ? & Salicornia spp. & & & $\checkmark$ & \\
\hline Redmaid & $*$ & $\begin{array}{l}\text { Calandrinia } \\
\text { spp. }\end{array}$ & & & $\checkmark$ & \\
\hline Salvia, Sage & $*$ & $\begin{array}{l}\text { Salvia spp., } \\
\text { Lepehinia,spp. }\end{array}$ & & & $\checkmark$ & \\
\hline Snakeroot & & $\begin{array}{l}\text { Sanicula } \\
\text { bipinnatifida }\end{array}$ & & $\checkmark$ & & \\
\hline Sedges & & Carex spp. & & & $\checkmark$ & \\
\hline
\end{tabular}




\begin{tabular}{|c|c|c|c|c|c|c|}
\hline $\begin{array}{l}\text { Common } \\
\text { Name }\end{array}$ & $\begin{array}{l}\mathrm{B} \\
\mathrm{P}\end{array}$ & $\begin{array}{l}\text { Scientific } \\
\text { Name }\end{array}$ & $\begin{array}{l}\text { Journals, } \\
\text { Diaries, } \\
\text { Images } \\
\end{array}$ & Specimens & $\begin{array}{l}\text { Ohlone } \\
\text { ethno- } \\
\text { graphies }\end{array}$ & $\begin{array}{l}\text { Visits to } \\
\text { Regional } \\
\text { Parks } \\
\end{array}$ \\
\hline Snowberry & $*$ & $\begin{array}{l}\text { Symphoricarpos } \\
\text { spp. }\end{array}$ & & & & $\checkmark$ \\
\hline Soaproot & $*$ & $\begin{array}{l}\text { Chlorogalum } \\
\text { spp. } \\
\text { Chenopodium } \\
\text { spp. }\end{array}$ & & & & $\checkmark$ \\
\hline Sycamore & & $\begin{array}{l}\text { Platanus } \\
\text { racemosa }\end{array}$ & $\checkmark$ & & & \\
\hline Tanoak & $*$ & $\begin{array}{l}\text { Lithocarpus } \\
\text { densiflorus }\end{array}$ & & & & $\checkmark$ \\
\hline $\begin{array}{l}\text { Tansy } \\
\text { Mustard }\end{array}$ & $*$ & $\begin{array}{l}\text { Descurainia } \\
\text { spp. }\end{array}$ & & & $\checkmark$ & \\
\hline Tule reed & & Scirpus spp. & & & $\checkmark$ & \\
\hline Valley oak & & Quercus lobata & & & & $\checkmark$ \\
\hline $\begin{array}{l}\text { Vineyards } \\
\text { (most likely } \\
\text { non-native } \\
\text { grapes) }\end{array}$ & - & & $\checkmark$ & & & \\
\hline Willows & $*$ & Salix spp. & & & & $\checkmark$ \\
\hline Wormwood & & Artemisia spp. & & & & $\checkmark$ \\
\hline
\end{tabular}

